\title{
Peripheral Administration of Tumor Necrosis Factor-Alpha Induces Neuroinflammation and Sickness but Not Depressive-Like Behavior in Mice
}

\author{
Steven Biesmans, ${ }^{1,2}$ Jan A. Bouwknecht, ${ }^{2}$ Luc Ver Donck, ${ }^{2}$ Xavier Langlois, ${ }^{2}$ Paul D. Acton, ${ }^{3}$ \\ Patrick De Haes, ${ }^{2}$ Nima Davoodi, ${ }^{1,2}$ Theo F. Meert, ${ }^{1,2}$ Niels Hellings, ${ }^{1}$ and Rony Nuydens ${ }^{2}$ \\ ${ }^{1}$ BIOMED, Hasselt University, Agoralaan C Building, 3590 Diepenbeek, Belgium \\ ${ }^{2}$ Neurosciences, Janssen Research \& Development, Division of Janssen Pharmaceutica NV, Turnhoutseweg 30, 2340 Beerse, Belgium \\ ${ }^{3}$ Molecular Imaging, Janssen Research \& Development LLC, Welsh \& McKean Roads, Spring House, PA 19477-0779, USA \\ Correspondence should be addressed to Rony Nuydens; rnuydens@its.jnj.com
}

Received 31 October 2014; Revised 4 March 2015; Accepted 6 March 2015

Academic Editor: Helton J. Reis

Copyright (C) 2015 Steven Biesmans et al. This is an open access article distributed under the Creative Commons Attribution License, which permits unrestricted use, distribution, and reproduction in any medium, provided the original work is properly cited.

\begin{abstract}
Clinical observations indicate that activation of the TNF- $\alpha$ system may contribute to the development of inflammation-associated depression. Here, we tested the hypothesis that systemic upregulation of TNF- $\alpha$ induces neuroinflammation and behavioral changes relevant to depression. We report that a single intraperitoneal injection of TNF- $\alpha$ in mice increased serum and brain levels of the proinflammatory mediators TNF- $\alpha$, IL-6, and MCP-1, in a dose- and time-dependent manner, but not IL- $1 \beta$. Protein levels of the anti-inflammatory cytokine IL-10 increased in serum but not in the brain. The transient release of immune molecules was followed by glial cell activation as indicated by increased astrocyte activation in bioluminescent Gfap-luc mice and elevated immunoreactivity against the microglial marker Ibal in the dentate gyrus of TNF- $\alpha$-challenged mice. Additionally, TNF- $\alpha$-injected mice were evaluated in a panel of behavioral tests commonly used to study sickness and depressive-like behavior in rodents. Our behavioral data imply that systemic administration of TNF- $\alpha$ induces a strong sickness response characterized by reduced locomotor activity, decreased fluid intake, and body weight loss. Depressive-like behavior could not be separated from sickness at any of the time points studied. Together, these results demonstrate that peripheral TNF- $\alpha$ affects the central nervous system at a neuroimmune and behavioral level.
\end{abstract}

\section{Introduction}

Clinical depression is a chronic, disabling psychiatric condition that affects over 120 million people worldwide [1]. It is predicted that, by 2030, depression will be the second leading cause of disability in the world [2]. Although its etiology remains poorly understood, it is generally accepted that depression is a multifactorial disorder with numerous interacting systems underlying its pathogenesis. A number of clinical observations suggest that dysregulation of the immune system might also play a role in the development of depression, at least in a subset of susceptible individuals. For example, depression frequently occurs as a comorbidity of medical conditions characterized by a chronic inflammatory component including rheumatoid arthritis [3], cancer [4], type 2 diabetes [5], stroke [6], obesity [7], and coronary artery disease [8]. Even in absence of other medical illnesses, depressed patients often show elevated circulating levels of inflammatory mediators such as proinflammatory cytokines and the acute-phase C-reactive protein $[9,10]$. Moreover, up to half of cancer and hepatitis $\mathrm{C}$ patients that receive therapeutic administration of proinflammatory cytokines eventually develop depressive symptoms [11-13].

There are several indications that tumor necrosis factor$\alpha$ (TNF- $\alpha)$ is one of the key cytokines involved in the pathogenesis of inflammation-associated depression. Recent meta-analyses confirmed that circulating levels of TNF- $\alpha$ are significantly higher in depressed patients compared with 
healthy control subjects $[10,14]$. Moreover, elevated plasma levels of TNF- $\alpha$ are associated with treatment resistance to conventional antidepressants [15]. In hepatitis $C$ patients that are chronically treated with interferon- $\alpha$, increased blood levels of TNF- $\alpha$ correlate with the development of depressive symptoms [16]. Furthermore, peripheral administration of anti-TNF- $\alpha$ antibodies improves depressed mood in patients suffering from psoriasis [17], Crohn's disease [18], and rheumatoid arthritis [19]. TNF- $\alpha$ antagonism has also been shown to improve treatment resistant depression in a subgroup of patients with high baseline inflammatory biomarkers [20].

Inflammation-associated depression is often studied in rodents by peripheral administration of immunostimulants such as bacterial lipopolysaccharide (LPS). It is known that systemic injection of LPS elicits a widespread immune response, characterized by the release of numerous immune mediators and the occurrence of sickness, a behavioral state comprised of symptoms such as malaise, lethargy, decreased motor activity and appetite, sleep disturbances, and increased sensitivity to pain $[21,22]$. There are some indications that this sickness response is followed by a phase of depressivelike behavior [23-25]. However, the characteristics of sickness can substantially confound the evaluation of depressive-like behavior in behavioral tests. For example, sick animals display reduced exploration, which can potentially interfere with measurements of immobility used to estimate behavioral despair in paradigms such as the forced swim (FST) and tail suspension test (TST) [26]. Moreover, sick animals eat and drink less, which can bias measures of sweetened fluid intake in assays designed to evaluate anhedonia (the inability to experience pleasure from naturally rewarding activities). Using a panel of behavioral paradigms in mice, we recently demonstrated that it is difficult to separate depressivelike behavior from sickness following acute peripheral LPS administration [27].

Based on the fact that systemic LPS administration induces a broad immune response and the clinical data linking TNF- $\alpha$ to human inflammation-associated depression, we hypothesized that peripheral administration of TNF- $\alpha$ itself may provide a more specific approach to study depressive-like behavior in mice. Indeed, systemic administration of TNF- $\alpha$ has already been shown to have central effects as indicated by increased proinflammatory gene expression in the brain and the development of sickness $[28,29]$. Moreover, intracerebroventricular (i.c.v.) injection of TNF- $\alpha$ was shown to lead to depressive-like behavior in mice [30, 31]. However, to our knowledge, no study has systematically assessed the effect of peripheral TNF$\alpha$ administration on neuroinflammation and depressivelike behavior over time. Therefore, the present series of experiments aimed at characterizing the central effects of systemic TNF- $\alpha$ injection by combining multiple techniques to quantify neuroinflammation and behavioral changes. First, serum and brain levels of immune mediators were quantified at several time points after systemic TNF- $\alpha$ administration. Next, transgenic bioluminescent Gfap-luc mice were used to evaluate the time course of TNF- $\alpha$-induced astrocyte activation, as a marker of glial cell activation in vivo. Then, the occurrence of glial cell activation was confirmed by immunohistochemistry using the microglial marker ionized calcium-binding adapter molecule 1 (Iba1). Finally, TNF- $\alpha$ injected mice were tested in a panel of behavioral paradigms to assess whether depressive-like behavior could be separated over time from sickness.

\section{Material and Methods}

2.1. Animals and TNF- $\alpha$. All animal care and use were performed in accordance with the Guide for the Care and Use of Laboratory Animals (NRC) and experimental protocols were approved by the Institutional Ethical Committee on Animal Experimentation, according to applicable regional law. Male NMRI mice were purchased from Charles River Laboratories (France), male wild-type FVB mice were purchased from Janvier (France), and male transgenic Gfap-luc mice (FVB/N$\operatorname{Tg}($ Gfap-luc)-Xen) were obtained from Taconic Laboratories (USA). The latter animals express luciferase under the transcriptional control of the glial fibrillary acidic protein (Gfap) promoter [32] and are commonly used as a model system for noninvasive quantification of astrocyte activation in living animals over time $[27,33,34]$. Unless mentioned otherwise, animals were housed in groups of 4 per cage under a normal 12:12 h light-dark cycle (lights on at 06:00 a.m. with a $30 \mathrm{~min}$ dim and rise phase). Food and water were available ad libitum.

Recombinant mouse TNF- $\alpha$ was purchased from Biolegend (product ID 575208) and dissolved in sterile phosphate buffered saline prior to injection.

2.2. Cytokine Measurements. 10-week-old male NMRI mice were injected intraperitoneally (i.p.) with $0,63,125$, or $250 \mu \mathrm{g} / \mathrm{kg}$ TNF- $\alpha$ ( $n=6-7$ per group) and sacrificed by decapitation at $2 \mathrm{~h}, 6 \mathrm{~h}$, or $24 \mathrm{~h}$. This dose range was based on results from the open field test (OFT) (see Section 2.5). Serum and whole brain samples were collected and processed as previously described [27]. Concentrations of interferon- $\gamma$ (IFN$\gamma$ ), interleukin- (IL-) $1 \beta$, IL-6, IL-10, monocyte chemoattractant protein-1 (MCP-1), and TNF- $\alpha$ were determined in each sample using a mouse cytokine/chemokine magnetic bead panel kit from Merck Millipore. All steps in the assay were conducted according to the manufacturer's instructions. Cytokine levels below detection limit were assigned a value equal to the lowest detectable value of that cytokine.

2.3. In Vivo Bioluminescence Imaging. Astrocyte activation in 10-week-old male Gfap-luc mice was quantified before (baseline) and at $2 \mathrm{~h}, 6 \mathrm{~h}, 24 \mathrm{~h}, 48 \mathrm{~h}, 72 \mathrm{~h}$, and $96 \mathrm{~h}$ after i.p. administration of either 0,63 , or $250 \mu \mathrm{g} / \mathrm{kg}$ TNF- $\alpha(n=7$ per group). Brain bioluminescence was detected as described previously $[27,35]$. Briefly, Gfap-luc mice were anesthetized by inhalation of $2 \%$ isoflurane in $1 \mathrm{~L} / \mathrm{min}$ oxygen, shaved on the head, and injected with $126 \mathrm{mg} / \mathrm{kg}$ D-luciferin (Promega, product ID E1601) in the tail vein. Three minutes later the animals were scanned with a charge-coupled device camera (IVIS Imaging System 200 Series, PerkinElmer) mounted on a dark box. Photon emission from the whole brain was measured using Living Image 3.2 software (PerkinElmer) in 
a region of interest (ROI) that was kept constant across mice. Bioluminescence coming from the ears was considered to be basal Gfap activity and was excluded from the ROI. Imaging signals were measured in physical units of surface radiance (photons $/ \mathrm{s} / \mathrm{cm}^{2} /$ steradian $[\mathrm{sr}]$ ).

2.4. Immunohistochemistry. 10-week-old male FVB mice were injected i.p. with vehicle or $250 \mu \mathrm{g} / \mathrm{kg}$ TNF- $\alpha(n=8$ per group) and tissue was collected $24 \mathrm{~h}$ later. Immunohistochemical staining of Ibal protein in the dentate gyrus of the hippocampus was performed using a rabbit polyclonal anti-Ibal primary antibody (1:500, Wako Chemicals) and a fluorescent Alexa 555 goat anti-rabbit secondary antibody (1:500, Invitrogen), as previously described [27].

2.5. Behavioral Tests. All behavioral tests were performed on separate groups of 10 -week-old male NMRI mice. The OFT and FST setups were custom-made and were described in detail previously [27].

Two independent OFTs were performed in this study. In the first OFT, mice were injected with $0,63,250$, or $1000 \mu \mathrm{g} / \mathrm{kg}$ TNF- $\alpha$ ( $n=10$ per group) and repeatedly tested at $2 \mathrm{~h}, 6 \mathrm{~h}$, $24 \mathrm{~h}$, and $48 \mathrm{~h}$ after administration. Two of the 10 mice that received $1000 \mu \mathrm{g} / \mathrm{kg}$ TNF- $\alpha$ died during the first $24 \mathrm{~h}$ after injection. Therefore, it was decided to take $250 \mu \mathrm{g} / \mathrm{kg}$ TNF$\alpha$ as the highest test dose for all experiments and to repeat the OFT with a vehicle and $125 \mu \mathrm{g} / \mathrm{kg}$ TNF- $\alpha$ group.

In the FST, mice ( $n=10$ per group) were injected with 0 , 63,125 , or $250 \mu \mathrm{g} / \mathrm{kg}$ TNF- $\alpha$ and tested at $2 \mathrm{~h}, 6 \mathrm{~h}, 24 \mathrm{~h}$, and $48 \mathrm{~h}$ after administration.

The sucrose preference test (SPT) started by singlehousing the animals in individually ventilated cages $(L \times W \times$ $H: 35 \times 31 \times 16 \mathrm{~cm}$; Tecniplast, Italy) fitted with two $250 \mathrm{~mL}$ drinking bottles and ad libitum access to food. Each bottle contained either filtered tap water or a 5\% sucrose solution. The location of the bottles on the cage was randomized during every exposure session with half of the animals receiving sucrose on the left and half on the right. The SPT protocol lasted for 5 days and consisted of a familiarization and a test phase. The familiarization phase started on day 1 by exposing all mice to one water- and one $5 \%$ sucrose-filled bottle (W/S) for $24 \mathrm{~h}$. On day 2, the animals had free access to two waterfilled bottles (W/W) until 4:00 p.m., after which they were fluid-deprived overnight. The test phase started on day 3 by injecting mice i.p. with $0,63,125$, or $250 \mu \mathrm{g} / \mathrm{kg}$ TNF- $\alpha$ ( $n=10$ per group). To test the effects of TNF- $\alpha$ at $2 \mathrm{~h}, 6 \mathrm{~h}$, $24 \mathrm{~h}$, and $48 \mathrm{~h}$, the animals were presented with W/S during a $1 \mathrm{~h}$ exposure period at these time points. Mice were fluiddeprived in between exposure periods. In order to avoid a protracted deprivation period between the $24 \mathrm{~h}$ and $48 \mathrm{~h}$ time points, mice were given access to W/W from 4:00 to 5:00 p.m. on day 4.

In the SPT study using a within-subject design it became clear that exposing the thirsty animals to W/S at $2 \mathrm{~h}$ affected the total volume intake at $6 \mathrm{~h}$ (less thirsty). To exclude that the effects of TNF- $\alpha$ were confounded by retesting the same animals over time, the SPT study was repeated in an independent between-subjects design study using separate groups of TNF- $\alpha$ challenged mice that were tested at either $6 \mathrm{~h}$ or $24 \mathrm{~h}$. These mice underwent the same familiarization phase as described above. At the beginning of the test phase, the animals were injected with $0,63,125$, or $250 \mu \mathrm{g} / \mathrm{kg}$ i.p. TNF- $\alpha$ ( $n=10$ per group). At $6 \mathrm{~h}$ after TNF- $\alpha$, mice from the $6 \mathrm{~h}$ time point group were exposed to W/S for a $1 \mathrm{~h}$ period. Animals from the $24 \mathrm{~h}$ time point were allowed to drink W/W for $1 \mathrm{~h}$ at $6 \mathrm{~h}$ after TNF- $\alpha$ in order to avoid a protracted deprivation period between TNF- $\alpha$ administration and the $24 \mathrm{~h}$ time point. At $24 \mathrm{~h}$, mice from the $24 \mathrm{~h}$ group were presented with W/S during a $1 \mathrm{~h}$ exposure period.

In both SPT studies, the amount drunk by a mouse was determined by subtracting the weight of a bottle at the start of an exposure period and at the end (taking fluid density as $1 \mathrm{~g} / \mathrm{mL}$ ). Total fluid intake was calculated as the total change in volume from both bottles combined. A fluid intake that was greater than the mean $+2 \mathrm{x}$ standard deviation was considered to be an invalid measure that probably resulted from leaking bottles. Invalid measures were replaced by the group mean of the relevant solution (water or sucrose). This occurred for less than $4 \%$ of all bottle measurements. Sucrose preference was calculated as the percentage of consumed sucrose solution of the total fluid intake.

2.6. Statistical Analysis. SPSS Statistics software version 20 (IBM Inc.) was used for data analysis. Analysis of variance (ANOVA) or repeated measures ANOVA (rmANOVA) was performed to determine the statistical significance of differences between treatment groups. To correct for potential violation of the sphericity assumption, a GreenhouseGeisser correction epsilon $(\varepsilon)$ was used for repeated measures analysis [36]. This correction multiplies both the numerator and the denominator degrees of freedom by $\varepsilon$ and the significance of the $F$-ratio is evaluated with the new degrees of freedom, resulting in a more conservative statistical test. To account for the skewness of the data distribution, bioluminescence measurements and cytokine concentrations were log-transformed prior to analysis. ANOVAs and rmANOVAs were considered statistically significant if $P<0.05$. When appropriate, post hoc comparisons were made by using an independent samples $t$-test with a Bonferroni-corrected $P$ value. For consistency between the analysis and the visualization of bioluminescence measurements and cytokine concentrations, the group means and its standard error of the mean (SEM) were back-transformed and visually presented on a logarithmic scale. All other data are expressed as mean \pm SEM on a linear scale.

\section{Results}

3.1. TNF- $\alpha$ Increases Immune Mediator Levels in Serum and Brain. To characterize the immunological response to peripheral TNF- $\alpha$ injection, serum and brain levels of several immune factors were quantified at $2 \mathrm{~h}, 6 \mathrm{~h}$, and $24 \mathrm{~h}$ after administration. Factorial ANOVA showed a significant time $\times$ dose interaction on serum levels of IL- 6, TNF- $\alpha$, and MCP$1(\mathrm{IL}-6: F(6,68)=13.4, P<0.001 ;$ TNF- $\alpha: F(6,66)=15.7$, $P<0.001$; MCP-1: $F(6,68)=7.2, P<0.001)$, a main effect of time and dose on serum levels of IL-10 (time: $F(2,68)=5.3$, $P<0.01$; dose: $F(3,68)=4.8, P<0.01)$, and a main 
effect of dose on serum levels of IL-1 $\beta(F(3,68)=3.2$, $P<0.05)$ and IFN- $\gamma(F(3,68)=5.8, P<0.01)$. Post hoc analysis demonstrated that serum levels of IL-6, TNF- $\alpha$, and MCP-1 peaked at $2 \mathrm{~h}$ after systemic injection of TNF- $\alpha$ and then gradually waned over time (Figure 1, left). The TNF- $\alpha$ induced release of IL-10 followed a different time course as serum levels of this cytokine were only elevated at $6 \mathrm{~h}$ after TNF- $\alpha$. At $24 \mathrm{~h}$, the serum concentrations of IL- 6 , TNF- $\alpha$, and IL-10 had returned to baseline values, while MCP-1 levels remained significantly elevated in mice that were injected with $250 \mu \mathrm{g} / \mathrm{kg}$ TNF- $\alpha$. Serum concentrations of IFN- $\gamma$ were higher across time points in animals that received $250 \mu \mathrm{g} / \mathrm{kg}$ TNF- $\alpha$, while IL- $1 \beta$ in serum was not significantly different at the post hoc level.

For brain tissue, a significant time $\times$ dose interaction was found on protein levels of IL-6, TNF- $\alpha$, and MCP-1 (IL-6: $F(6,67)=6.4, P<0.001$; TNF- $\alpha: F(6,67)=70.2, P<0.001$; MCP-1: $F(6,67)=15.4, P<0.001)$ and a main effect of dose on IFN- $\gamma$ levels $(F(3,67)=4.0, P<0.05)$. No significant effect of time or dose could be detected on brain levels of IL-1 $\beta$ or IL-10. Post hoc analysis revealed that brain levels of IL- 6 and TNF- $\alpha$ peaked at $2 \mathrm{~h}$ and had dissipated by $6 \mathrm{~h}$ (Figure 1, right). However, at $6 \mathrm{~h}$ there was still a trend for elevated IL- 6 levels in mice that had received $250 \mu \mathrm{g} / \mathrm{kg}$ TNF$\alpha$. Comparable to the time course of its release in serum, brain levels of MCP-1 remained strongly elevated from $2 \mathrm{~h}$ until $6 \mathrm{~h}$ after treatment. At $24 \mathrm{~h}$, there was still a trend for increased MCP-1 levels in mice injected with $250 \mu \mathrm{g} / \mathrm{kg}$ TNF- $\alpha$. Brain concentrations of IFN- $\gamma$ were decreased across time points in animals from the 63 and $125 \mu \mathrm{g} / \mathrm{kg}$ TNF- $\alpha$ group, but not in mice that received $250 \mu \mathrm{g} / \mathrm{kg}$ TNF- $\alpha$ group.

3.2. TNF- $\alpha$ Induces Glial Cell Activation. To quantify the effects of systemic TNF- $\alpha$ administration on astrocyte activation over time, Gfap-luc mice were injected i.p. with different doses of TNF- $\alpha$ and bioluminescence was measured at specific time points. Factorial rmANOVA revealed a significant time $\times$ dose interaction $(F(12,84)=5.8 ; P<0.001 ; \varepsilon=$ 0.53 ) for photons emitted per second in the brain ROI. Post hoc analysis demonstrated that, at $6 \mathrm{~h}$ after administration, a strong bioluminescent signal was present in the brain of TNF- $\alpha$-injected mice (Figure 2). This signal was higher in mice injected with $250 \mu \mathrm{g} / \mathrm{kg}$ TNF- $\alpha$ as compared to mice that received $63 \mu \mathrm{g} / \mathrm{kg}$ TNF- $\alpha$. Brain bioluminescence in mice treated with $63 \mu \mathrm{g} / \mathrm{kg}$ TNF- $\alpha$ reached control levels at $24 \mathrm{~h}$, while it took up to $72 \mathrm{~h}$ to normalize for animals injected with $250 \mu \mathrm{g} / \mathrm{kg}$ TNF- $\alpha$.

In order to confirm TNF- $\alpha$-induced activation of glial cells by using a different technique and focusing on another cell type, immunohistochemistry was performed using a microglial activation marker. The expression of Ibal was quantified in the hippocampal dentate gyrus at $24 \mathrm{~h}$ after systemic injection of vehicle or $250 \mu \mathrm{g} / \mathrm{kg}$ TNF- $\alpha$. This brain structure was chosen based on its association with stress and depression [37-39]. Pairwise comparison demonstrated that immunoreactivity against Ibal in the dentate gyrus at $24 \mathrm{~h}$ was significantly higher in TNF- $\alpha$-injected mice when compared to mice that received vehicle $(F(1,13)=7.3, P<0.05)$ (Figure 3).
3.3. TNF- $\alpha$ Causes Sickness but No Depressive-Like Behavior. Sickness behavior in rodents is commonly evaluated by measuring changes in body weight and by assessing their locomotor activity in the OFT. Unfortunately, 2 out of 10 mice that were injected with $1000 \mu \mathrm{g} / \mathrm{kg}$ TNF- $\alpha$ died within $24 \mathrm{~h}$ after administration. These subjects were removed from the analyses, resulting in a group size of $n=8$ for this dose. rmANOVA showed a time $\times$ dose interaction for change in body weight $(F(6,68)=24.9 ; P<0.001 ; \varepsilon=0.95)$. Post hoc analysis demonstrated that there was a dose-dependent weight reduction at $24 \mathrm{~h}$ and $48 \mathrm{~h}$ after TNF- $\alpha$ administration (Figure 4(a)). Mice that were injected with $63 \mu \mathrm{g} / \mathrm{kg}$ and $250 \mu \mathrm{g} / \mathrm{kg}$ TNF- $\alpha$ started to gain weight at $48 \mathrm{~h}$, while mice in the $1000 \mu \mathrm{g} / \mathrm{kg}$ TNF- $\alpha$ group continued to lose weight.

A significant time $\times$ dose interaction was found for total distance travelled in the $\operatorname{OFT}(F(9,102)=10.2 ; P<$ $0.001 ; \varepsilon=0.70)$. At $2 \mathrm{~h}$ after systemic application, TNF$\alpha$ reduced locomotor activity in a dose-dependent manner (Figure $4(\mathrm{c})$ ). By $6 \mathrm{~h}$, the total distance travelled by mice administered with $63 \mu \mathrm{g} / \mathrm{kg}$ TNF- $\alpha$ had normalized to control levels, while it further declined in animals from the $250 \mu \mathrm{g} / \mathrm{kg}$ and $1000 \mu \mathrm{g} / \mathrm{kg}$ group. At $24 \mathrm{~h}$, animals from the $250 \mu \mathrm{g} / \mathrm{kg}$ group had recovered whereas this took up to $48 \mathrm{~h}$ for mice injected with $1000 \mu \mathrm{g} / \mathrm{kg}$ TNF- $\alpha$.

Based on the mortality rate of $20 \%$ in mice that received $1000 \mu \mathrm{g} / \mathrm{kg}$ TNF- $\alpha$, it was decided to take $250 \mu \mathrm{g} / \mathrm{kg}$ TNF$\alpha$ as the highest dose and to introduce a $125 \mu \mathrm{g} / \mathrm{kg}$ TNF$\alpha$ group in all of the behavioral experiments that followed. To test the effect of this additional dose on body weight and locomotor activity, a second, independent OFT was performed. rmANOVA showed a time $\times$ dose interaction for change in body weight $(F(2,36)=6.0 ; P<0.05 ; \varepsilon=$ $0.74)$ and a main effect of time $(F(3,54)=14.2 ; P<0.001 ; \varepsilon=$ $0.66)$ and dose $(F(1,18)=7.0 ; P<0.05 ; \varepsilon=0.66)$ for distance travelled in the OFT. Post hoc analysis revealed that the weight of mice injected with $125 \mu \mathrm{g} / \mathrm{kg}$ TNF- $\alpha$ was reduced at $24 \mathrm{~h}$, but not anymore at $48 \mathrm{~h}$ (Figure $4(\mathrm{~b})$ ). Moreover, systemic administration of $125 \mu \mathrm{g} / \mathrm{kg}$ TNF- $\alpha$ decreased the distance travelled at $6 \mathrm{~h}$, but not at any of the other time points measured (Figure 4(d)).

In the FST an animal is placed in a water-filled cylinder from which it cannot escape. Behavioral despair can be evaluated in this paradigm by quantifying duration of immobility, which can be confirmed by measuring the total distance the animal swims. rmANOVA revealed a significant effect of time, but not of dose, for total distance $(F(3,108)=20.4$; $P<0.001 ; \varepsilon=0.77)$ and immobility time $(F(3,108)=38.0$; $P<0.001 ; \varepsilon=0.75)$. Post hoc analysis showed that compared to the $2 \mathrm{~h}$ time point all animals swam less and remained immobile longer at $6 \mathrm{~h}, 24 \mathrm{~h}$, and $48 \mathrm{~h}$ after TNF- $\alpha$ (Figures 4(e) and 4(f)). This happened independently of the TNF$\alpha$ dose given and indicates habituation to the experimental procedure during retesting.

In the SPT an animal's preference for a sweetened solution versus water is measured. This paradigm allows evaluating sickness by assessing total volume intake while reductions in sucrose preference can be used as a measure for anhedonia, which is a key symptom of depression. rmANOVA demonstrated a significant effect of time $(F(3,108)=26.0$; 

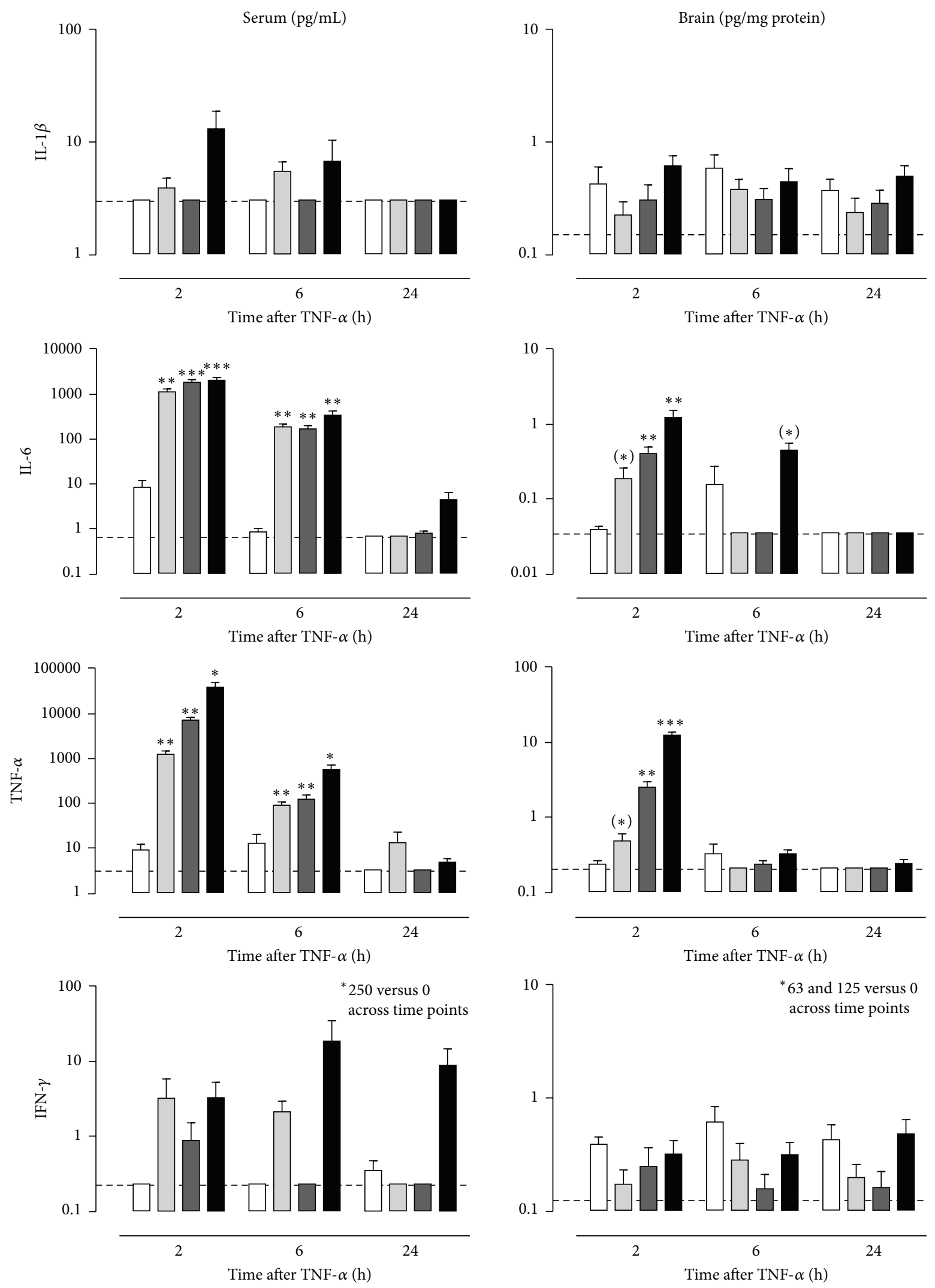

$\square 0 \mu \mathrm{g} / \mathrm{kg}$ TNF- $\alpha$

$\square 63 \mu \mathrm{g} / \mathrm{kg}$ TNF- $\alpha$

$125 \mu \mathrm{g} / \mathrm{kg}$ TNF- $\alpha$

- $250 \mu \mathrm{g} / \mathrm{kg}$ TNF- $\alpha$

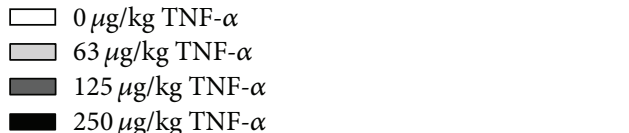

FIgure 1: Continued. 

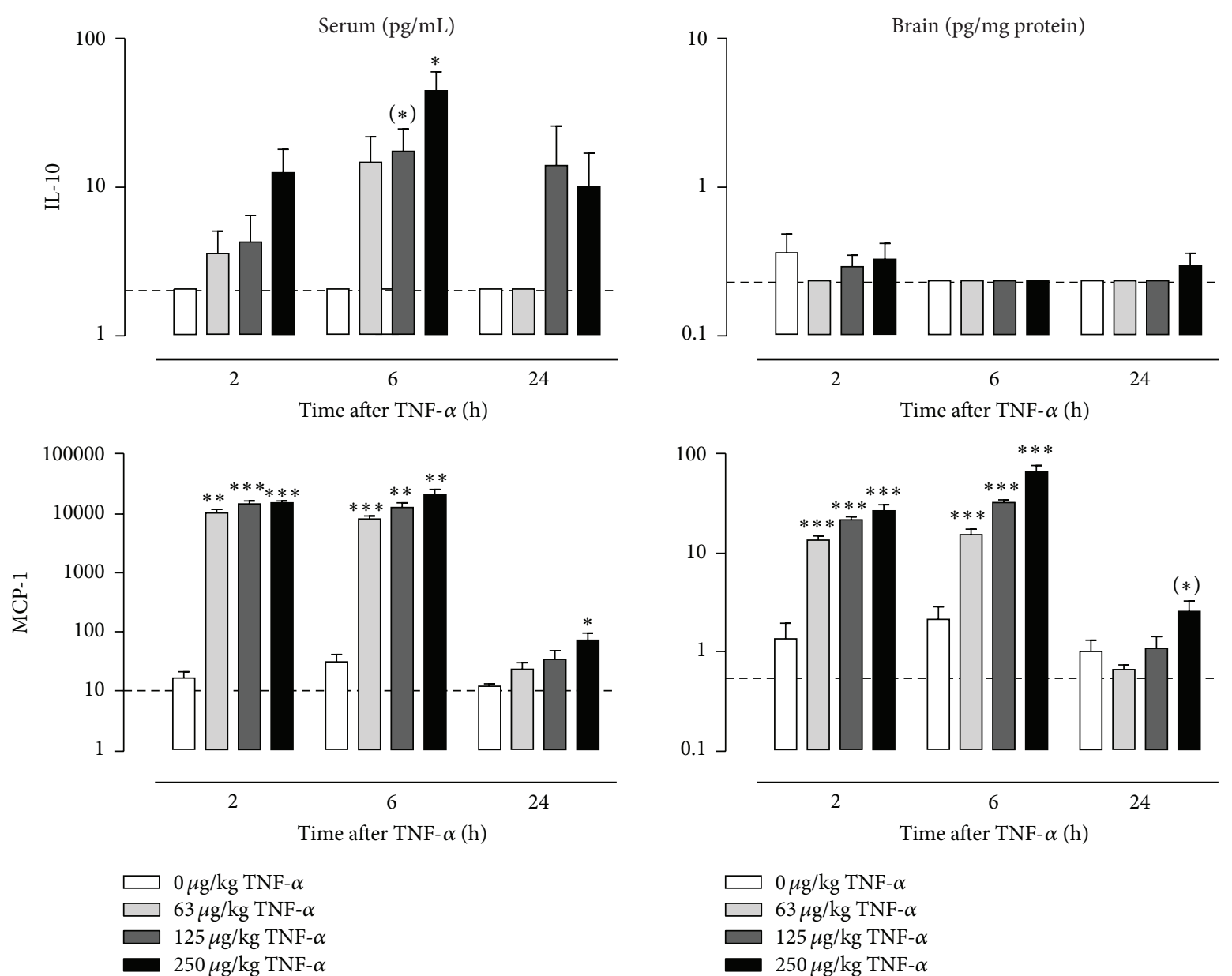

FIGURE 1: Peripheral TNF- $\alpha$ administration induces the release of immune mediators in serum and brain. Time course of serum (left) and brain concentrations (right) of interleukin- (IL-) $1 \beta$, IL-6, tumor necrosis factor- $\alpha$ (TNF- $\alpha$ ), interferon- $\gamma$ (IFN- $\gamma$ ), IL-10, and monocyte chemoattractant protein-1 (MCP-1) as measured at $2 \mathrm{~h}, 6 \mathrm{~h}$, and $24 \mathrm{~h}$ after i.p. TNF- $\alpha$ injection. Note that serum concentrations are shown as $\mathrm{pg} / \mathrm{mL}$ while brain levels are expressed in $\mathrm{pg} / \mathrm{mg}$ protein. Dashed lines indicate the detection limit of the measured analyte. Graphs are plotted as mean + SEM $(n=6-7$ per group). Data were analyzed by ANOVA followed by independent samples $t$-test. $(*) 0.1<P<0.05$; ${ }^{*} P<0.05 ;{ }^{* *} P<0.01 ;{ }^{* * *} P<0.001$ compared to $0 \mu \mathrm{g} / \mathrm{kg}$ TNF- $\alpha$.

$P<0.001 ; \varepsilon=0.98)$ and dose $(F(3,36)=4.0 ; P<0.05$ $\varepsilon=0.98)$ for total volume intake. Moreover, there was an effect of time $(F(3,108)=23.5 ; P<0.001 ; \varepsilon=0.96)$ and a trend for dose $(F(3,36)=2.6 ; P=0.07 ; \varepsilon=0.96)$ for sucrose preference. At $2 \mathrm{~h}$ and $6 \mathrm{~h}$ after administration, animals that were injected with $250 \mu \mathrm{g} / \mathrm{kg}$ TNF- $\alpha$ drank significantly less than vehicle-treated controls, while mice that received $125 \mu \mathrm{g} / \mathrm{kg}$ TNF- $\alpha$ only showed reduced fluid intake at $6 \mathrm{~h}$ (Figure 4(g)). Sucrose preference was lower at $2 \mathrm{~h}$ and $6 \mathrm{~h}$ in animals injected with $250 \mu \mathrm{g} / \mathrm{kg}$ TNF- $\alpha$ but not at lower doses (Figure 4(h)).

All animals including the vehicle-injected controls showed reduced total volume intake at $6 \mathrm{~h}$ when compared to the other time points. This probably resulted from the fact that the fluid-deprived mice were allowed to drink at $2 \mathrm{~h}$ and hence were less thirsty at $6 \mathrm{~h}$. To exclude that the effects of TNF- $\alpha$ were confounded by retesting the same animals over time, the SPT study was repeated for the $6 \mathrm{~h}$ and $24 \mathrm{~h}$ time points using separate groups of TNF- $\alpha$ challenged mice for each time point. In this second SPT study there was a main effect of time $(F(1,72)=5.7, P<0.05)$ and dose $(F(3,72)=9.0, P<0.001)$ for total volume intake and a main effect of dose $(F(3,72)=3.3, P<0.05)$, but not time, for sucrose preference. Post hoc analysis revealed that using naive animals for each time point stabilized total volume intake in mice injected with vehicle (Figure 5(a)). At $6 \mathrm{~h}$ after administration, all TNF- $\alpha$-treated mice drank less than their vehicle-injected controls. Volume intake at $24 \mathrm{~h}$ was only significantly reduced in mice administered with $250 \mu \mathrm{g} / \mathrm{kg}$ TNF- $\alpha$. Sucrose preference across both time points was reduced in mice that received $125 \mu \mathrm{g} / \mathrm{kg} \mathrm{TNF}-\alpha$, but not at any of the other doses (Figure 5(b)).

\section{Discussion}

A substantial set of literature data indicates a link between activation of the immune system and depression, at least in subpopulations of patients. Several clinical observations 


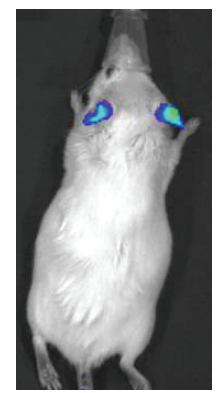

$0 \mu \mathrm{g} / \mathrm{kg}$ TNF- $\alpha$

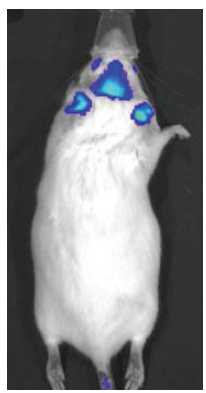

$63 \mu \mathrm{g} / \mathrm{kg}$ TNF- $\alpha$

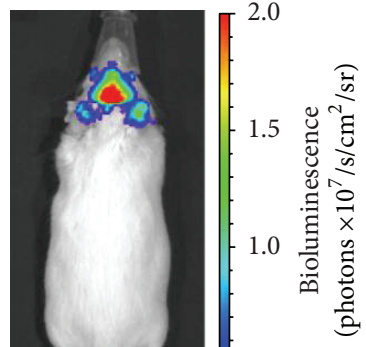

$250 \mu \mathrm{g} / \mathrm{kg}$ TNF- $\alpha$
0.5

(1)
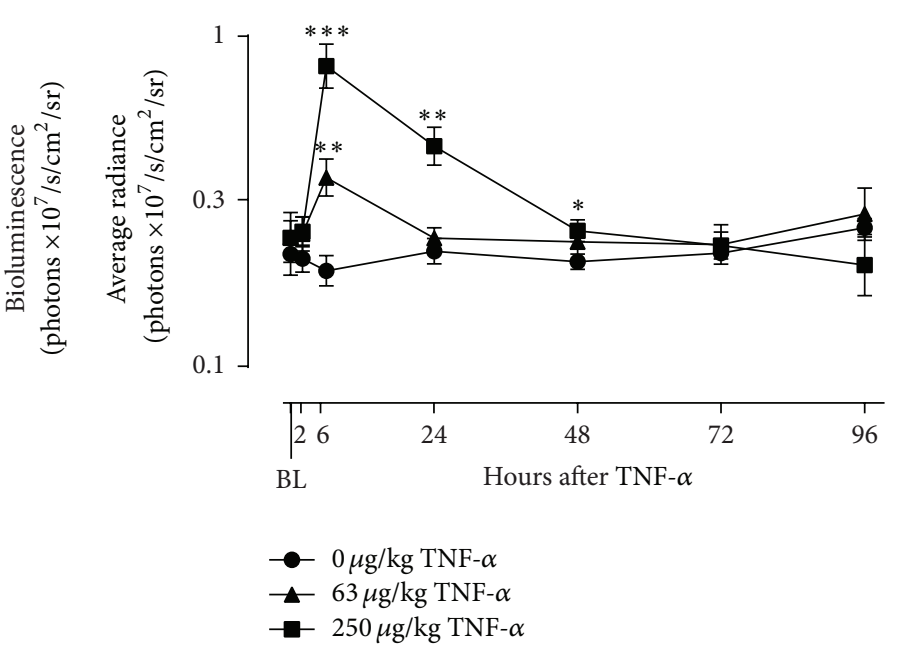

(b)

Figure 2: TNF- $\alpha$ activates astrocytes in a dose- and time-dependent manner. Intraperitoneal injection of TNF- $\alpha$ caused a clear bioluminescent signal in the brain of Gfap-luc mice, as shown in representative images taken at $6 \mathrm{~h}$ after injection (a). This signal peaked at $6 \mathrm{~h}$ and then gradually waned over time (b). The color scale indicates the number of photons emitted from the animal per second. The graph is plotted as mean \pm SEM ( $n=7$ per group). Data were analyzed by rmANOVA followed by independent samples $t$-test. BL: baseline. ${ }^{*} P<0.05 ;{ }^{* *} P<0.01 ;{ }^{* * *} P<0.001$ compared to $0 \mu \mathrm{g} / \mathrm{kg}$ TNF- $\alpha$.
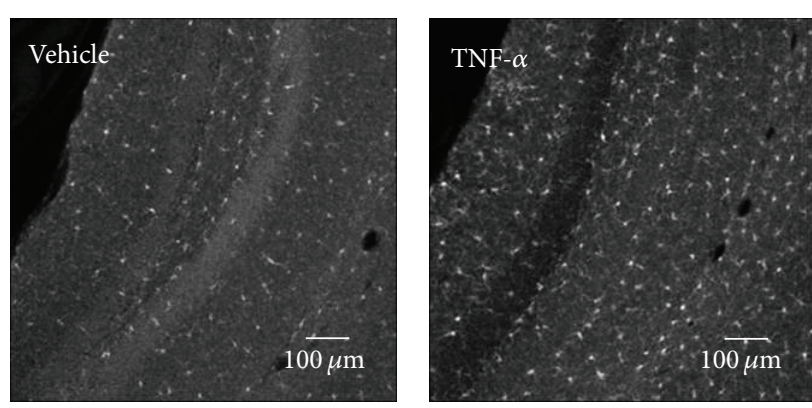

(a)

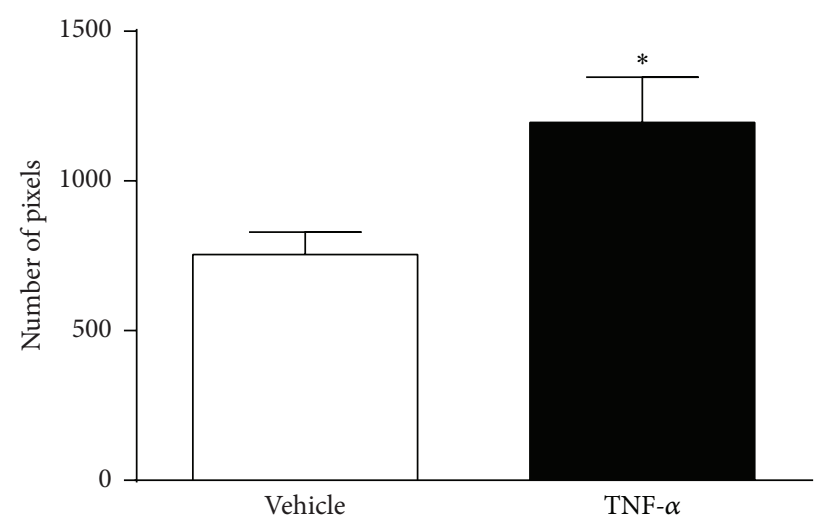

(b)

FIGURE 3: TNF- $\alpha$ increases Ibal immunoreactivity in the dentate gyrus. TNF- $\alpha(250 \mu \mathrm{g} / \mathrm{kg}$, i.p.) caused a strong upregulation of the microglial activation marker Ibal in the hippocampal dentate gyrus at $24 \mathrm{~h}$ after administration. Representative images (10x) (a) and image quantifications of $n=8$ per group (b). Graph is plotted as mean + SEM. Data were analyzed by ANOVA followed by independent samples $t$-test. ${ }^{*} P<0.05$ compared to vehicle.

suggest that TNF- $\alpha$ is one of the key cytokines contributing to the development of inflammation-associated depression. In this series of experiments, we tested whether peripheral administration of TNF- $\alpha$ in mice is able to induce neuroinflammation as well as behavioral changes relevant to human depression.

TNF- $\alpha$ is a pleiotrophic cytokine that plays an important role in the early stages of inflammatory responses and in triggering the release of downstream immune molecules [4042]. To assess the effect of peripheral TNF- $\alpha$ administration on immune activation in mice, we measured serum and brain levels of a selection of immune mediators. As expected, systemic injection of TNF- $\alpha$ caused a robust dose-dependent increase in circulating levels of TNF- $\alpha$. Due to the fact that recombinant mouse TNF- $\alpha$ was administered, it was not possible to discriminate injected from endogenously produced TNF- $\alpha$. Previous studies have shown that systemic injection of TNF- $\alpha$ upregulates cytokine gene expression in the liver $[29,43]$, thereby indicating that TNF- $\alpha$ is capable of eliciting a broad immunological response. In line with these findings, we found that peripheral TNF- $\alpha$ administration increased circulating levels of the proinflammatory immune mediators IL-6 and MCP-1. Moreover, the peak release of these factors was followed by an increase in the serum concentration of IL-10. This cytokine is a potent anti-inflammatory mediator that plays a role in attenuating inflammatory responses and 
Study 1

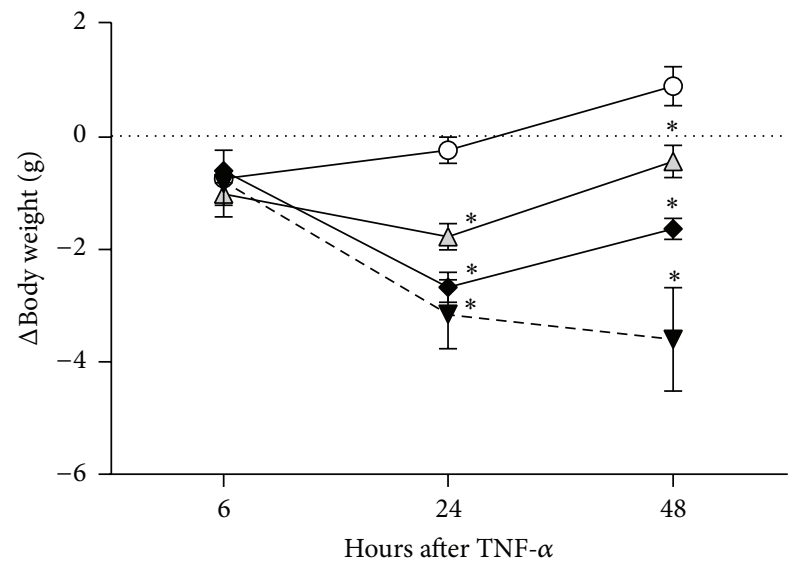

(a)

Study 1

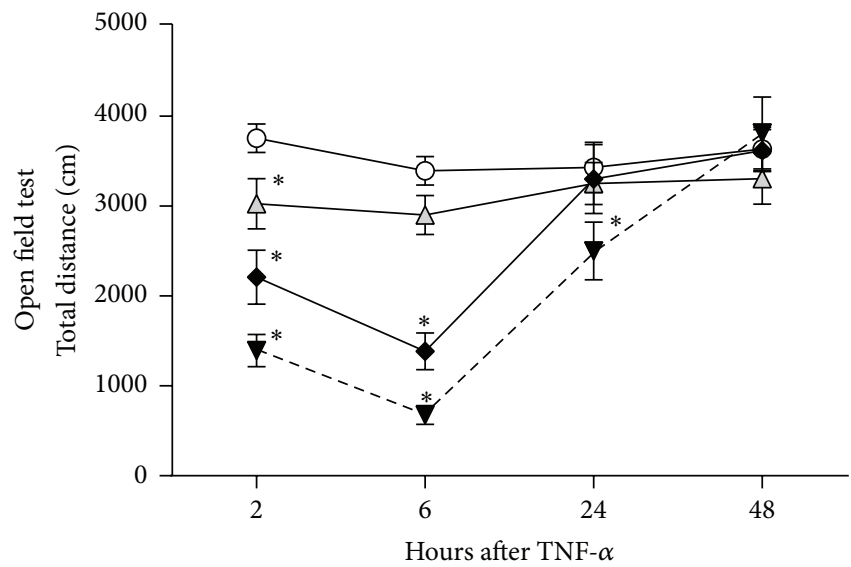

(c)

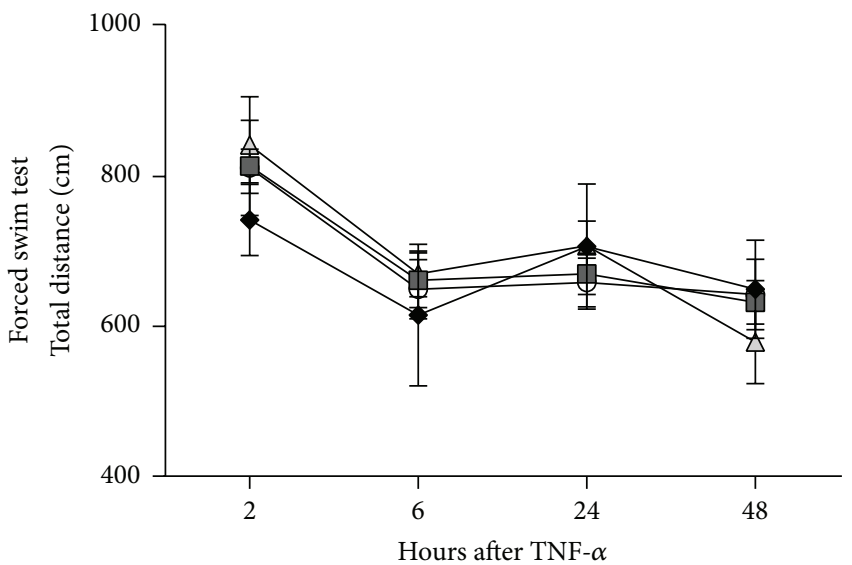

-O- $0 \mu \mathrm{g} / \mathrm{kg}$ TNF- $\alpha$

$\neg 63 \mu \mathrm{g} / \mathrm{kg}$ TNF- $\alpha$

$\neg 125 \mu \mathrm{g} / \mathrm{kg}$ TNF- $\alpha$

- $250 \mu \mathrm{g} / \mathrm{kg}$ TNF- $\alpha$

- $-1000 \mu \mathrm{g} / \mathrm{kg}$ TNF- $\alpha$

(e)
Study 2

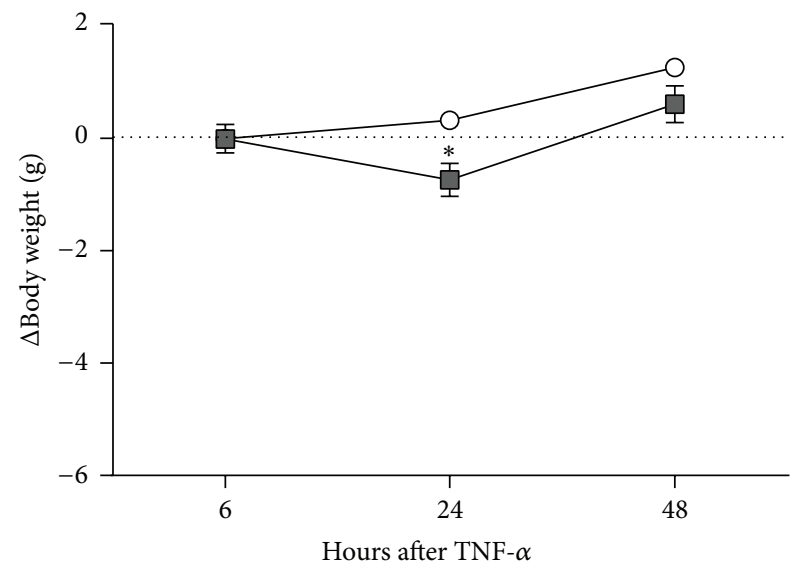

(b)

Study 2

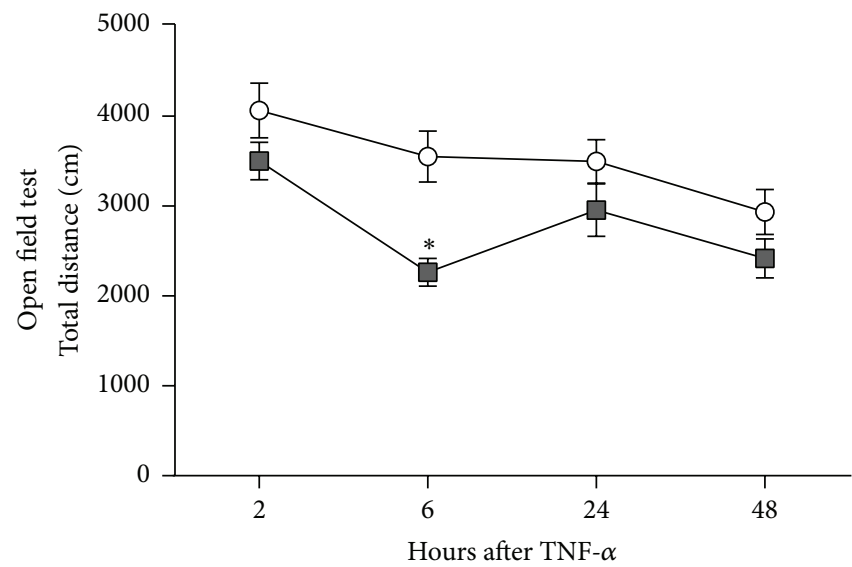

(d)

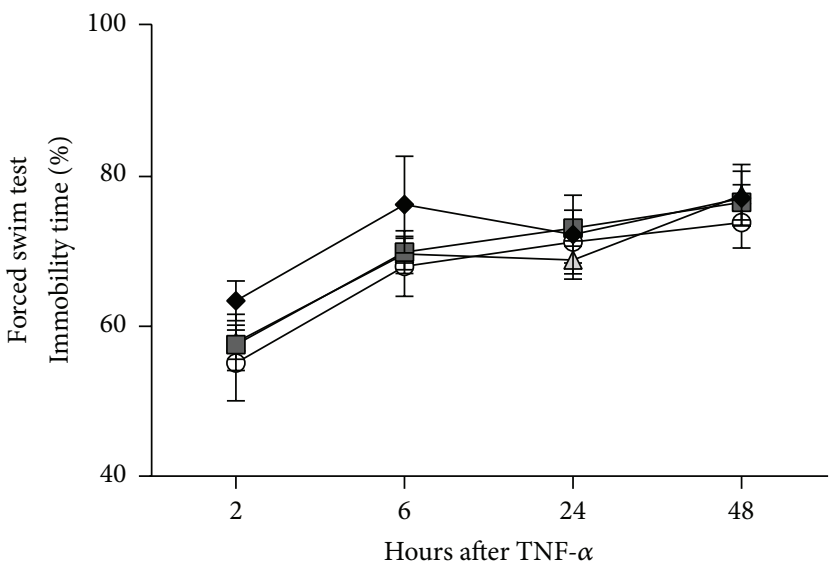

-O- $0 \mu \mathrm{g} / \mathrm{kg}$ TNF- $\alpha$

$\neg 63 \mu \mathrm{g} / \mathrm{kg}$ TNF- $\alpha$

$\neg 125 \mu \mathrm{g} / \mathrm{kg}$ TNF- $\alpha$

- $250 \mu \mathrm{g} / \mathrm{kg}$ TNF- $\alpha$

- $-1000 \mu \mathrm{g} / \mathrm{kg}$ TNF- $\alpha$

(f)

FIgURE 4: Continued. 


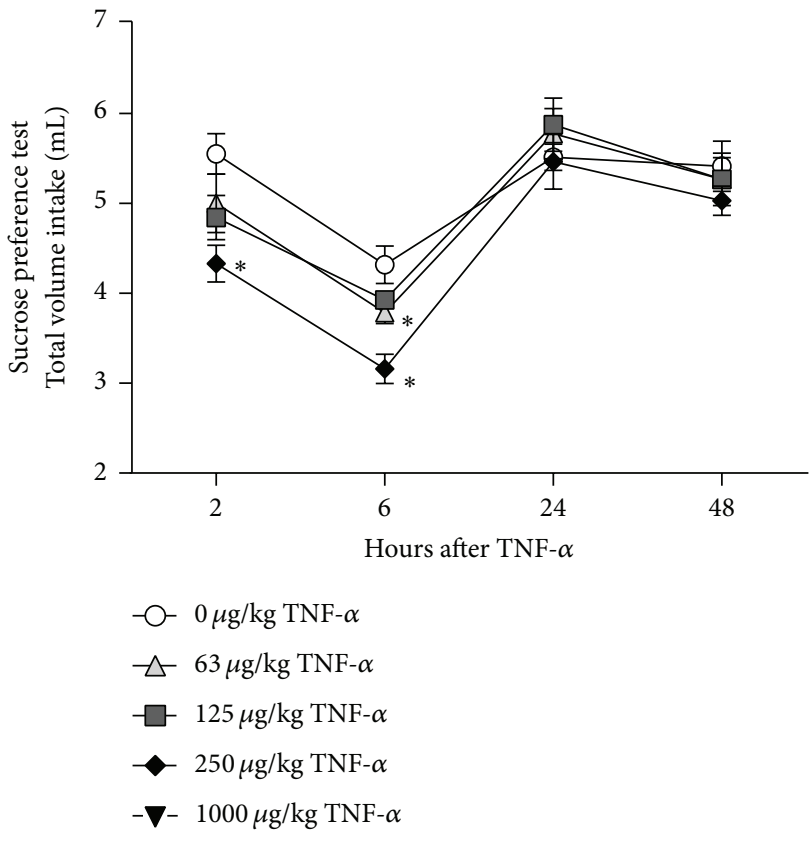

(g)

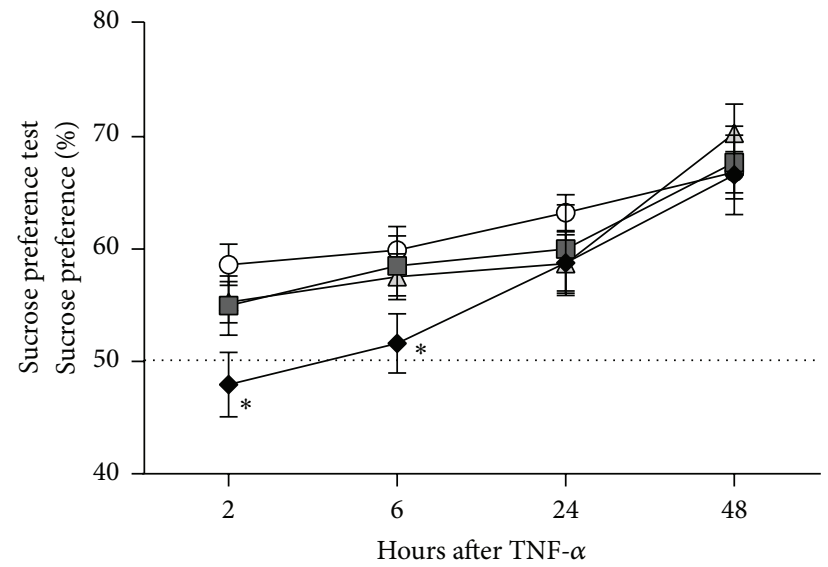

$$
\begin{aligned}
& -0-0 \mu \mathrm{g} / \mathrm{kg} \text { TNF- } \alpha \\
& \triangle 63 \mu \mathrm{g} / \mathrm{kg} \text { TNF- } \alpha \\
& -125 \mu \mathrm{g} / \mathrm{kg} \text { TNF- } \alpha \\
& -250 \mu \mathrm{g} / \mathrm{kg} \text { TNF- } \alpha \\
& -\nabla-1000 \mu \mathrm{g} / \mathrm{kg} \text { TNF- } \alpha
\end{aligned}
$$

(h)

FIGURE 4: TNF- $\alpha$ causes sickness, but no clear depressive-like behavior. Systemic injection of TNF- $\alpha$ caused body weight loss ((a)-(b)), reduced locomotor activity in the open field test ((c)-(d)), and decreased total fluid intake in the sucrose preference test (g). Measures of behavioral despair in the forced swim test were not affected by administration of TNF- $\alpha$ ((e)-(f)). A high dose of TNF- $\alpha$ did decrease sucrose preference in the SPT (h) but this can be considered biologically irrelevant due to the overlapping time course of sickness. The dashed line in the sucrose preference test indicates the chance level (50\%) for sucrose preference. Please note that the $y$-axis does not start at 0 for the forced swim and sucrose preference test data. Graphs are plotted as mean \pm SEM $(n=10$ per group, except $n=8$ for $1000 \mu \mathrm{g} / \mathrm{kg}$ TNF- $\alpha$ ). Data were analyzed by rmANOVA followed by independent samples $t$-test. ${ }^{*} \mathrm{P}<0.05$ compared to $0 \mu \mathrm{g} / \mathrm{kg}$ TNF- $\alpha$.

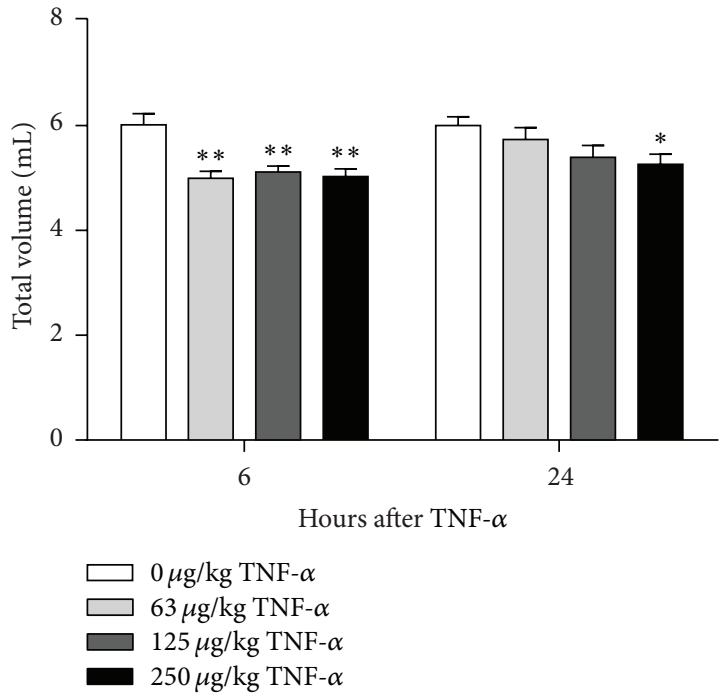

(a)

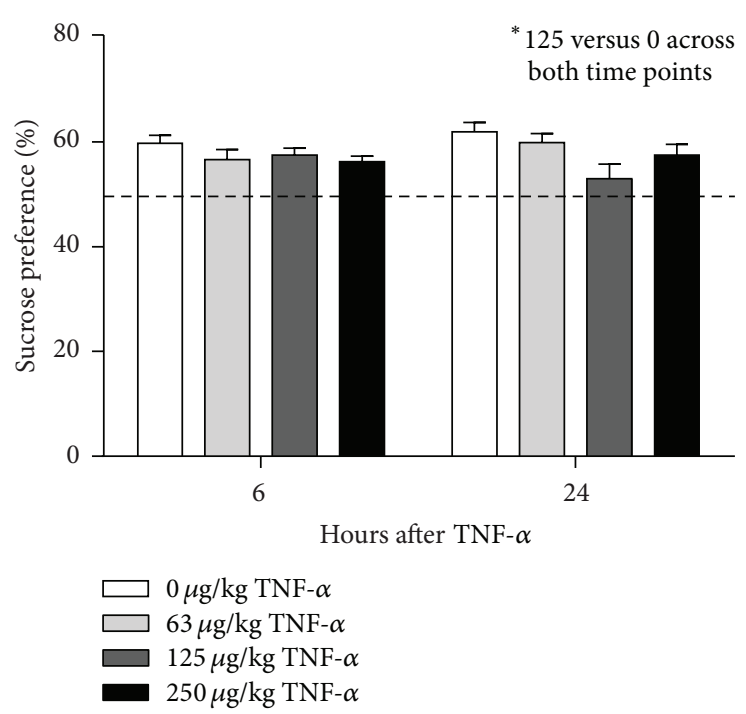

(b)

FIGURE 5: Peripheral TNF- $\alpha$ administration reduces total fluid intake (a) but does not induce clear anhedonia (b) in the sucrose preference test. Separate groups of naive animals were injected i.p. with TNF- $\alpha$ and tested in the SPT at either $6 \mathrm{~h}$ or $24 \mathrm{~h}$. Dashed line indicates chance level for sucrose preference. Graphs are plotted as mean $+\operatorname{SEM}(n=10$ per group). Data were analyzed by ANOVA followed by independent samples $t$-test. ${ }^{*} P<0.05 ;{ }^{* *} P<0.01$ compared to $0 \mu \mathrm{g} / \mathrm{kg}$ TNF- $\alpha$ at the same time point. 
suppressing the expression of proinflammatory cytokines [44]. Apart from MCP-1 levels in mice treated with the highest dose of TNF- $\alpha$, the concentration of all cytokines had returned to baseline values at $24 \mathrm{~h}$. This indicates that the inflammatory response to a single injection of TNF- $\alpha$ is short-lasting. Our cytokine data corroborates with findings from a recent study where systemic TNF- $\alpha$ was also reported to increase circulating levels of pro- and anti-inflammatory mediators [29]. However, not all of our findings are in line with those described by Skelly et al. In our study, for example, TNF- $\alpha$-induced increases in IL- 6 were of a higher magnitude than the ones previously described [29]. Moreover, in contrast to Skelly's data, we were not able to detect statistically significant increases in IL- $1 \beta$ levels. This was unexpected as TNF- $\alpha$ is known to induce the expression and release of IL-1 $\beta[29,43]$. These discrepancies may in part result from differences in experimental protocols, including the use of dissimilar recombinant $\mathrm{TNF}-\alpha$, mouse strains and gender, blood sampling methods, and potentially the sensitivity of the techniques used to quantify cytokine levels.

Several in vitro studies indicate that cross-regulation occurs between TNF- $\alpha$ and interferons [45-49]. However, results from these studies are often contradictory and the effect of TNF- $\alpha$ on interferon synthesis seems to depend on the inflammatory condition, the type of interferon (type I or type II), and the cell type studied [50]. Effects of TNF- $\alpha$ on IFN- $\gamma$ levels in vivo are poorly described in literature. Our study did not detect a robust effect of TNF- $\alpha$ administration on IFN- $\gamma$ levels in either serum or brain.

Cytokines from the periphery can pass the BBB through various mechanisms and access the brain [51]. TNF- $\alpha$ influences these processes in several ways. For example, TNF- $\alpha$ increases the permeability of the BBB [52], thereby facilitating the passage of relatively large molecules such as cytokines from the blood into the brain. Moreover, TNF- $\alpha$ stimulates the release of the chemokine MCP-1, which increases BBB permeability even further and subsequently drives the infiltration of leukocytes into the brain [53]. Accordingly, we found that brain levels of TNF- $\alpha$, IL-6, and MCP-1 transiently increased in response to peripheral TNF- $\alpha$ administration. As we did not assess the integrity of the $\mathrm{BBB}$, it is not clear whether these immune mediators entered the brain through a leaky BBB and/or if they were actively produced and released locally in the brain. It is possible that a fraction of the measured brain cytokine levels originated in the periphery. However, several studies described that bolus injected TNF- $\alpha$ is rapidly cleared and has a short half-life of up to 20 minutes [54-56]. These findings together with reports of cytokine gene expression in the brain following peripheral TNF- $\alpha$ administration [29] indicate that de novo transcription of these molecules does occur within the brain.

Besides elevated concentrations of proinflammatory cytokines, depressed patients frequently display increased circulating levels of MCP-1 [57, 58]. This chemokine is an important regulator of brain inflammation following a peripheral immune challenge $[59,60]$. Additionally, MCP1 has been suggested to act as a modulator of neuronal activity and neuroendocrine functions $[61,62]$. In our study, peripheral TNF- $\alpha$ caused a robust release of MCP-1 both in serum and in whole brain tissue. As MCP-1 is preferentially expressed in the hippocampus and other neuroanatomical regions linked to depressive symptoms [62], it may play an important role in the development of inflammationassociated depression.

The neuroinflammatory response to peripheral TNF- $\alpha$ was further characterized using a transgenic mouse line that expresses luciferase under the transcriptional control of the Gfap promoter. GFAP is an intermediate filament protein that is predominantly expressed by astrocytes, and its expression is upregulated when astrocytes are activated [63]. These Gfap-luc mice thus allow noninvasive quantification of Gfap mRNA expression, as a marker of astrocyte activation, in living mice over time. We found that systemic administration of TNF- $\alpha$ caused a strong dose- and time-dependent activation of astrocytes. This TNF- $\alpha$-induced astrocyte activation occurred after the peak release of proinflammatory cytokines and lasted for 2 days, thereby suggesting that the brain sequelae to a peripheral immune challenge may propagate in absence of the initial stimulus.

Although quantification of glial cell activation using bioluminescence imaging offers numerous advantages, this technique does not allow for spatial discrimination of specific brain regions. However, previous work has shown that neuroinflammatory responses to a peripheral immune challenge are brain region specific [64-66]. To confirm glial activation at a cellular level, focusing on another cell type and a specific brain area, we quantified the expression of Ibal in the hippocampus. This brain structure is associated with depression and has previously been shown to display immune cell activation following a peripheral immune challenge [27, $67,68]$. In the brain, Ibal is primarily expressed by microglia and its expression is upregulated upon microglial activation [69]. Consistent with measures of astrocyte activation in Gfap-luc mice, TNF- $\alpha$ injection increased Ibal immunoreactivity in the hippocampus of FVB wild-type mice. This indicates that, in addition to astrocytes, microglia also show signs of activation following peripheral TNF- $\alpha$ administration.

Activated microglia are known to release proinflammatory cytokines, particularly TNF- $\alpha$ and IL- $1 \beta$, but brain levels of these cytokines were not elevated at the time point at which we observed microglial activation. This may partly be explained by the fact that we quantified cytokine levels in the whole brain and not in specific brain regions. Moreover, assessing protein levels of cytokines in the brain is hampered by the limited sensitivity of available quantification techniques. This problem could be overcome by quantifying transcript expression using quantitative PCR, which is more sensitive approach compared to measuring protein levels of immune mediators in brain tissue. Cytokine as well as chemokine activity, however, is not only limited by gene expression, but also regulated at the posttranscriptional and posttranslational level $[44,70,71]$. Therefore, assessing protein levels of cytokines is suggested to be a more accurate indicator of cytokine activity [72]. Irrespective of differences in assay sensitivity, our data align with results from previous 
studies showing that cytokine expression in the hippocampus and hypothalamus was no longer elevated at $24 \mathrm{~h}$ after peripheral TNF- $\alpha$ administration [29].

To our knowledge, no study has systematically assessed the time course of sickness and depressive-like behavior following systemic TNF- $\alpha$ administration. After confirming that peripheral injection of TNF- $\alpha$ induces a central inflammatory response, we evaluated the time course of TNF- $\alpha$ induced behavioral changes across a panel of assays commonly used to study sickness and depressive-like behavior in rodents. Our behavioral data demonstrate that TNF- $\alpha$ dose dependently induces sickness during the first $24 \mathrm{~h}$ after systemic administration. This could be seen as a decrease in body weight, reduced exploration in the OFT, and suppressed drinking in the SPT. In contrast to i.c.v. administration [30, 31], peripherally injected TNF- $\alpha$ did not affect measures of behavioral despair in the FST. Moreover, mild signs of anhedonia observed in the SPT overlapped with the time course of sickness and can therefore be considered biologically irrelevant. One limitation in our study is the withinsubject design for the individual behavioral paradigms. This approach allowed reduction of animal numbers but also led to habituation of the mice to some of the experimental paradigms. Such habituation effects were observed in vehicleinjected control animals upon retesting in the FST (i.e., less swimming and longer immobility time) and in the SPT (i.e., less drinking at $6 \mathrm{~h}$ than at $2 \mathrm{~h}$ ). To rule out that effects of TNF- $\alpha$ were missed because of habituation during retesting, the SPT study was repeated using separate groups of naive animals for the $6 \mathrm{~h}$ and $24 \mathrm{~h}$ time points. From this experiment it also became clear that peripheral TNF- $\alpha$ administration induced sickness, but not anhedonia. Taken together, the behavioral data indicate that acute systemic injection of TNF- $\alpha$ is not a reliable model to induce depressive-like behavior in mice. Based on the strong but short-lasting effects of TNF- $\alpha$ on neuroinflammation and behavior, it may be possible that prolonged or intermittent administration of TNF- $\alpha$, leading to chronic upregulation of cytokines, offers a more valid approach to study depressivelike behavior in rodents. Such chronic TNF- $\alpha$ administration would mimic the human situation where inflammationassociated depression is believed to develop on a background of sustained, low-grade inflammation.

\section{Conclusions}

The present set of experiments using a variety of techniques and readouts showed that systemically administered TNF- $\alpha$ induced a strong but temporal release of immune mediators in the circulation and the brain. This release of inflammatory factors was followed by glial cell activation, as measured by astrocyte activation in the Gfap-luc mouse and increased Ibal immunoreactivity in the hippocampus of FVB wild-type mice. Additionally, systemic administration of TNF- $\alpha$ led to a strong sickness response and mild signs of anhedonia. Due to the overlapping time course of these behavioral states it was not possible to unambiguously distinguish depressivelike behavior from sickness. Taken together, these results demonstrate that TNF- $\alpha$ in the periphery affects the central nervous system by inducing neuroinflammatory processes and behavioral changes.

\section{Conflict of Interests}

The authors declare that there is no conflict of interests regarding the publication of this paper.

\section{References}

[1] J.-P. Lépine and M. Briley, "The increasing burden of depression," Neuropsychiatric Disease and Treatment, vol. 7, pp. 3-7, 2011.

[2] C. D. Mathers and D. Loncar, "Projections of global mortality and burden of disease from 2002 to 2030," PLoS Medicine, vol. 3, no. 11, pp. 2011-2030, 2006.

[3] C. Dickens, L. McGowan, D. Clark-Carter, and F. Creed, "Depression in rheumatoid arthritis: a systematic review of the literature with meta-analysis," Psychosomatic Medicine, vol. 64, no. 1, pp. 52-60, 2002.

[4] D. L. Evans, D. S. Charney, L. Lewis et al., "Mood disorders in the medically ill: scientific review and recommendations," Biological Psychiatry, vol. 58, no. 3, pp. 175-189, 2005.

[5] R. J. Anderson, K. E. Freedland, R. E. Clouse, and P. J. Lustman, "The prevalence of comorbid depression in adults with diabetes: a meta-analysis," Diabetes Care, vol. 24, no. 6, pp. 1069-1078, 2001.

[6] J. A. Schwartz, N. M. Speed, J. A. Brunberg, T. L. Brewer, M. Brown, and J. F. Greden, "Depression in stroke rehabilitation," Biological Psychiatry, vol. 33, no. 10, pp. 694-699, 1993.

[7] N. M. Petry, D. Barry, R. H. Pietrzak, and J. A. Wagner, "Overweight and obesity are associated with psychiatric disorders: results from the national epidemiologic survey on alcohol and related conditions," Psychosomatic Medicine, vol. 70, no. 3, pp. 288-297, 2008

[8] I. S. Khawaja, J. J. Westermeyer, P. Gajwani, and R. E. Feinstein, "Depression and coronary artery disease: the association, mechanisms and therapeutic implications," Psychiatry, vol. 6, no. 1, pp. 38-51, 2009.

[9] M. B. Howren, D. M. Lamkin, and J. Suls, "Associations of depression with c-reactive protein, IL-1, and IL-6: a metaanalysis," Psychosomatic Medicine, vol. 71, no. 2, pp. 171-186, 2009.

[10] Y. Dowlati, N. Herrmann, W. Swardfager et al., "A meta-analysis of cytokines in major depression," Biological Psychiatry, vol. 67, no. 5, pp. 446-457, 2010.

[11] L. Capuron, A. Ravaud, and R. Dantzer, "Early depressive symptoms in cancer patients receiving interleukin 2 and/or interferon alfa-2b therapy," Journal of Clinical Oncology, vol. 18, no. 10, pp. 2143-2151, 2000.

[12] S. Bonaccorso, A. Puzella, V. Marino et al., "Immunotherapy with interferon-alpha in patients affected by chronic hepatitis $\mathrm{C}$ induces an intercorrelated stimulation of the cytokine network and an increase in depressive and anxiety symptoms," Psychiatry Research, vol. 105, no. 1-2, pp. 45-55, 2001. 
[13] S. Bonaccorso, V. Marino, M. Biondi, F. Grimaldi, F. Ippoliti, and M. Maes, "Depression induced by treatment with interferonalpha in patients affected by hepatitis C virus," Journal of Affective Disorders, vol. 72, no. 3, pp. 237-241, 2002.

[14] Y. Liu, R. C.-M. Ho, and A. Mak, "Interleukin (IL)-6, tumour necrosis factor alpha (TNF- $\alpha$ ) and soluble interleukin-2 receptors (sIL-2R) are elevated in patients with major depressive disorder: a meta-analysis and meta-regression," Journal of Affective Disorders, vol. 139, no. 3, pp. 230-239, 2012.

[15] S. M. O’Brien, P. Scully, P. Fitzgerald, L. V. Scott, and T. G. Dinan, "Plasma cytokine profiles in depressed patients who fail to respond to selective serotonin reuptake inhibitor therapy," Journal of Psychiatric Research, vol. 41, no. 3-4, pp. 326-331, 2007.

[16] C. L. Raison, A. S. Borisov, B. J. Woolwine, B. Massung, G. Vogt, and A. H. Miller, "Interferon- $\alpha$ effects on diurnal hypothalamicpituitary-adrenal axis activity: relationship with proinflammatory cytokines and behavior," Molecular Psychiatry, vol. 15, no. 5, pp. 535-547, 2010.

[17] S. Tyring, A. Gottlieb, K. Papp et al., "Etanercept and clinical outcomes, fatigue, and depression in psoriasis: double-blind placebo-controlled randomised phase III trial," The Lancet, vol. 367, no. 9504, pp. 29-35, 2006.

[18] P. Persoons, S. Vermeire, K. Demyttenaere et al., "The impact of major depressive disorder on the short- and long-term outcome of Crohn's disease treatment with infliximab," Alimentary Pharmacology and Therapeutics, vol. 22, no. 2, pp. 101-110, 2005.

[19] F. Uguz, C. Akman, S. Kucuksarac, and O. Tufekci, "Anti-tumor necrosis factor-alpha therapy is associated with less frequent mood and anxiety disorders in patients with rheumatoid arthritis," Psychiatry and Clinical Neurosciences, vol. 63, no. 1, pp. 5055, 2009.

[20] C. L. Raison, R. E. Rutherford, B. J. Woolwine et al., "A randomized controlled trial of the tumor necrosis factor antagonist infliximab for treatment-resistant depression: the role of baseline inflammatory biomarkers," Archives of General Psychiatry, vol. 70, no. 1, pp. 31-41, 2013.

[21] R. Dantzer, "Cytokine-induced sickness behavior: where do we stand?" Brain, Behavior, and Immunity, vol. 15, no. 1, pp. 7-24, 2001.

[22] B. L. Hart, "Biological basis of the behavior of sick animals," Neuroscience and Biobehavioral Reviews, vol. 12, no. 2, pp. 123137, 1988.

[23] F. Frenois, M. Moreau, J. O’Connor et al., "Lipopolysaccharide induces delayed FosB/DeltaFosB immunostaining within the mouse extended amygdala, hippocampus and hypothalamus, that parallel the expression of depressive-like behavior," Psychoneuroendocrinology, vol. 32, no. 5, pp. 516-531, 2007.

[24] C. J. Henry, Y. Huang, A. Wynne et al., "Minocycline attenuates lipopolysaccharide (LPS)-induced neuroinflammation, sickness behavior, and anhedonia," Journal of Neuroinflammation, vol. 5, article 15, 2008.

[25] J. C. O’Connor, M. A. Lawson, C. André et al., "Lipopolysaccharide-induced depressive-like behavior is mediated by indoleamine 2,3-dioxygenase activation in mice," Molecular Psychiatry, vol. 14, no. 5, pp. 511-522, 2009.

[26] R. Dantzer, J. C. O'Connor, G. G. Freund, R. W. Johnson, and K. W. Kelley, "From inflammation to sickness and depression: when the immune system subjugates the brain," Nature Reviews Neuroscience, vol. 9, no. 1, pp. 46-56, 2008.
[27] S. Biesmans, T. F. Meert, J. A. Bouwknecht et al., "Systemic immune activation leads to neuroinflammation and sickness behavior in mice," Mediators of Inflammation, vol. 2013, Article ID 271359, 14 pages, 2013.

[28] R. M. Bluthé, M. Pawlowski, S. Suarez et al., "Synergy between tumor necrosis factor $\alpha$ and interleukin-1 in the induction of sickness behavior in mice," Psychoneuroendocrinology, vol. 19, no. 2, pp. 197-207, 1994.

[29] D. T. Skelly, E. Hennessy, M.-A. Dansereau, and C. Cunningham, "A systematic analysis of the peripheral and CNS effects of systemic LPS, IL-1 $\beta$, [corrected] TNF- $\alpha$ and IL- 6 challenges in C57BL/6 mice," PLoS ONE, vol. 8, no. 7, Article ID e69123, 2013.

[30] M. P. Kaster, V. M. Gadotti, J. B. Calixto, A. R. S. Santos, and A. L. S. Rodrigues, "Depressive-like behavior induced by tumor necrosis factor-alpha in mice," Neuropharmacology, vol. 62, no. 1, pp. 419-426, 2012.

[31] L. M. Manosso, V. B. Neis, M. Moretti et al., "Antidepressant-like effect of $\alpha$-tocopherol in a mouse model of depressivelike behavior induced by TNF- $\alpha$," Progress in NeuroPsychopharmacology and Biological Psychiatry, vol. 46, pp. 48-57, 2013.

[32] L. Zhu, S. Ramboz, D. Hewitt, L. Boring, D. S. Grass, and A. F. Purchio, "Non-invasive imaging of GFAP expression after neuronal damage in mice," Neuroscience Letters, vol. 367, no. 2, pp. 210-212, 2004.

[33] P. Cordeau Jr., M. Lalancette-Hébert, Y. C. Weng, and J. Kriz, "Live imaging of neuroinflammation reveals sex and estrogen effects on astrocyte response to ischemic injury," Stroke, vol. 39, no. 3, pp. 935-942, 2008.

[34] J. Luo, P. Ho, L. Steinman, and T. Wyss-Coray, "Bioluminescence in vivo imaging of autoimmune encephalomyelitis predicts disease," Journal of Neuroinflammation, vol. 5, article 6, 2008.

[35] S. Biesmans, P. D. Acton, C. Cotto et al., "Effect of stress and peripheral immune activation on astrocyte activation in transgenic bioluminescent Gfap-luc mice," Glia, 2015.

[36] M. W. Vasey and J. F. Thayer, "The continuing problem of false positives in repeated measures ANOVA in psychophysiology: a multivariate solution," Psychophysiology, vol. 24, no. 4, pp. 479486, 1987.

[37] Y. Che, J. F. Wang, L. Shao, and L. T. Young, "Oxidative damage to RNA but not DNA in the hippocampus of patients with major mental illness," Journal of Psychiatry and Neuroscience, vol. 35, no. 5, pp. 296-302, 2010.

[38] N. D. Hanson, M. J. Owens, and C. B. Nemeroff, "Depression, antidepressants, and neurogenesis: a critical reappraisal," Neuropsychopharmacology, vol. 36, no. 13, pp. 2589-2602, 2011.

[39] A. Surget, A. Tanti, E. D. Leonardo et al., "Antidepressants recruit new neurons to improve stress response regulation," Molecular Psychiatry, vol. 16, no. 12, pp. 1177-1188, 2011.

[40] M. M. Rahman and G. McFadden, "Modulation of tumor necrosis factor by microbial pathogens," PLoS pathogens, vol. 2, no. 2 , article e4, 2006.

[41] I. A. Clark, L. M. Alleva, and B. Vissel, "The roles of TNF in brain dysfunction and disease," Pharmacology \& Therapeutics, vol. 128, no. 3, pp. 519-548, 2010.

[42] P. Charles, M. J. Elliott, D. Davis et al., "Regulation of cytokines, cytokine inhibitors, and acute-phase proteins following antiTNF-alpha therapy in rheumatoid arthritis," The Journal of Immunology, vol. 163, no. 3, pp. 1521-1528, 1999. 
[43] L. Qin, X. Wu, M. L. Block et al., "Systemic LPS causes chronic neuroinflammation and progressive neurodegeneration," Glia, vol. 55, no. 5, pp. 453-462, 2007.

[44] S. S. Iyer and G. Cheng, "Role of interleukin 10 transcriptional regulation in inflammation and autoimmune disease," Critical Reviews in Immunology, vol. 32, no. 1, pp. 23-63, 2012.

[45] A. K. Palucka, J.-P. Blanck, L. Bennett, V. Pascual, and J. Banchereau, "Cross-regulation of TNF and IFN- $\alpha$ in autoimmune diseases," Proceedings of the National Academy of Sciences of the United States of America, vol. 102, no. 9, pp. 3372-3377, 2005.

[46] A. Yarilina, K.-H. Park-Min, T. Antoniv, X. Hu, and L. B. Ivashkiv, "TNF activates an IRF1-dependent autocrine loop leading to sustained expression of chemokines and STAT1dependent type I interferon-response genes," Nature Immunology, vol. 9, no. 4, pp. 378-387, 2008.

[47] J. Coclet-Ninin, J.-M. Dayer, and D. Burger, "Interferon-beta not only inhibits interleukin- $1 \beta$ and tumor necrosis factor- $\alpha$ but stimulates interleukin-1 receptor antagonist production in human peripheral blood mononuclear cells," European Cytokine Network, vol. 8, no. 4, pp. 345-349, 1997.

[48] I. Sauer, B. Schaljo, C. Vogl et al., "Interferons limit inflammatory responses by induction of tristetraprolin," Blood, vol. 107, no. 12, pp. 4790-4797, 2006.

[49] B. B. Aggarwal and R. Pandita, "Both type I and type II interferons down-regulate human tumor necrosis factor receptors in human hepatocellular carcinoma cell line Hep G2. Role of protein kinase C," FEBS Letters, vol. 337, no. 1, pp. 99-102, 1994.

[50] T. Cantaert, D. Baeten, P. P. Tak, and L. G. M. van Baarsen, "Type I IFN and TNF $\alpha$ cross-regulation in immune-mediated inflammatory disease: basic concepts and clinical relevance," Arthritis Research and Therapy, vol. 12, no. 5, article 219, 2010.

[51] L. Capuron and A. H. Miller, "Immune system to brain signaling: neuropsychopharmacological implications," Pharmacology and Therapeutics, vol. 130, no. 2, pp. 226-238, 2011.

[52] H. Liu, P. G. M. Luiten, U. L. M. Eisel, M. J. L. Dejongste, and R. G. Schoemaker, "Depression after myocardial infarction: TNF- $\alpha$-induced alterations of the blood-brain barrier and its putative therapeutic implications," Neuroscience \& Biobehavioral Reviews, vol. 37, no. 4, pp. 561-572, 2013.

[53] C. D’Mello, T. Le, and M. G. Swain, “Cerebral microglia recruit monocytes into the brain in response to tumor necrosis factora signaling during peripheral organ inflammation," The Journal of Neuroscience, vol. 29, no. 7, pp. 2089-2102, 2009.

[54] D. A. Flick and G. E. Gifford, "Pharmacokinetics of murine tumor necrosis factor," Journal of Immunopharmacology, vol. 8, no. 1, pp. 89-97, 1986.

[55] M. Blick, S. A. Sherwin, M. Rosenblum, and J. Gutterman, "Phase I study of recombinant tumor necrosis factor in cancer patients," Cancer Research, vol. 47, no. 11, pp. 2986-2989, 1987.

[56] P. B. Chapman, T. J. Lester, E. S. Casper et al., "Clinical pharmacology of recombinant human tumor necrosis factor in patients with advanced cancer," Journal of Clinical Oncology, vol. 5, no. 12, pp. 1942-1951, 1987.

[57] J. E. Piletz, A. Halaris, O. Iqbal et al., "Pro-inflammatory biomakers in depression: treatment with venlafaxine," World Journal of Biological Psychiatry, vol. 10, no. 4, pp. 313-323, 2009.

[58] N. M. Simon, K. McNamara, C. W. Chow et al., "A detailed examination of cytokine abnormalities in Major Depressive
Disorder," European Neuropsychopharmacology, vol. 18, no. 3, pp. 230-233, 2008.

[59] W. L. Thompson, W. J. Karpus, and L. J. Van Eldik, "MCP1-deficient mice show reduced neuroinflammatory responses and increased peripheral inflammatory responses to peripheral endotoxin insult," Journal of Neuroinflammation, vol. 5, article 35, 2008.

[60] J. Cazareth, A. Guyon, C. Heurteaux, J. Chabry, and A. PetitPaitel, "Molecular and cellular neuroinflammatory status of mouse brain after systemic lipopolysaccharide challenge: importance of CCR2/CCL2 signaling," Journal of Neuroinflammation, vol. 11, no. 1, p. 132, 2014.

[61] G. Banisadr, R.-D. Gosselin, P. Mechighel, W. Rostène, P. Kitabgi, and S. M. Parsadaniantz, "Constitutive neuronal expression of CCR2 chemokine receptor and its colocalization with neurotransmitters in normal rat brain: functional effect of MCP-1/CCL2 on calcium mobilization in primary cultured neurons," Journal of Comparative Neurology, vol. 492, no. 2, pp. 178-192, 2005.

[62] G. Banisadr, R.-D. Gosselin, P. Mechighel, P. Kitabgi, W. Rostène, and S. M. Parsadaniantz, "Highly regionalized neuronal expression of monocyte chemoattractant protein-1 (MCP1/CCL2) in rat brain: evidence for its colocalization with neurotransmitters and neuropeptides," Journal of Comparative Neurology, vol. 489, no. 3, pp. 275-292, 2005.

[63] J. L. Ridet, S. K. Malhotra, A. Privat, and F. H. Gage, "Reactive astrocytes: cellular and molecular cues to biological function," Trends in Neurosciences, vol. 20, no. 12, pp. 570-577, 1997.

[64] C. André, J. C. O'Connor, K. W. Kelley, J. Lestage, R. Dantzer, and N. Castanon, "Spatio-temporal differences in the profile of murine brain expression of proinflammatory cytokines and indoleamine 2,3-dioxygenase in response to peripheral lipopolysaccharide administration," Journal of Neuroimmunology, vol. 200, no. 1-2, pp. 90-99, 2008.

[65] L. Gautron, P. Lafon, M. Chaigniau, G. Tramu, and S. Layé, "Spatiotemporal analysis of signal transducer and activator of transcription 3 activation in rat brain astrocytes and pituitary following peripheral immune challenge," Neuroscience, vol. 112, no. 3, pp. 717-729, 2002.

[66] P. Bossù, D. Cutuli, I. Palladino et al., "A single intraperitoneal injection of endotoxin in rats induces long-lasting modifications in behavior and brain protein levels of TNF- $\alpha$ and IL-18," Journal of Neuroinflammation, vol. 9, article 101, 2012.

[67] Y. Diz-Chaves, M. Astiz, M. J. Bellini, and L. M. Garcia-Segura, "Prenatal stress increases the expression of proinflammatory cytokines and exacerbates the inflammatory response to LPS in the hippocampal formation of adult male mice," Brain, Behavior, and Immunity, vol. 28, pp. 196-206, 2013.

[68] B. C. Borges, R. Rorato, J. Antunes-Rodrigues, and L. L. K. Elias, "Glial cell activity is maintained during prolonged inflammatory challenge in rats," Brazilian Journal of Medical and Biological Research, vol. 45, no. 8, pp. 784-791, 2012.

[69] D. Ito, Y. Imai, K. Ohsawa, K. Nakajima, Y. Fukuuchi, and S. Kohsaka, "Microglia-specific localisation of a novel calcium binding protein, Ibal," Molecular Brain Research, vol. 57, no. 1, pp. 1-9, 1998.

[70] G. W. Novotny, M. Lundh, M. B. Backe et al., "Transcriptional and translational regulation of cytokine signaling in inflammatory beta-cell dysfunction and apoptosis," Archives of Biochemistry and Biophysics, vol. 528, no. 2, pp. 171-184, 2012. 
[71] T. Hamilton, X. Li, M. Novotny et al., "Cell type- and stimulusspecific mechanisms for post-transcriptional control of neutrophil chemokine gene expression," Journal of Leukocyte Biology, vol. 91, no. 3, pp. 377-383, 2012.

[72] M. A. Erickson and W. A. Banks, "Cytokine and chemokine responses in serum and brain after single and repeated injections of lipopolysaccharide: multiplex quantification with path analysis," Brain, Behavior, and Immunity, vol. 25, no. 8, pp. 16371648, 2011. 

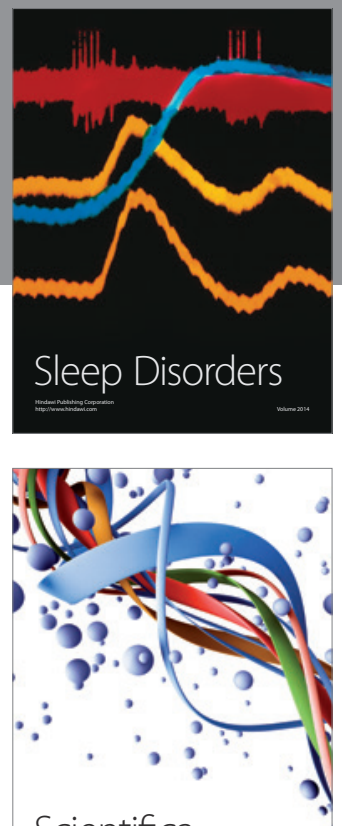

Scientifica
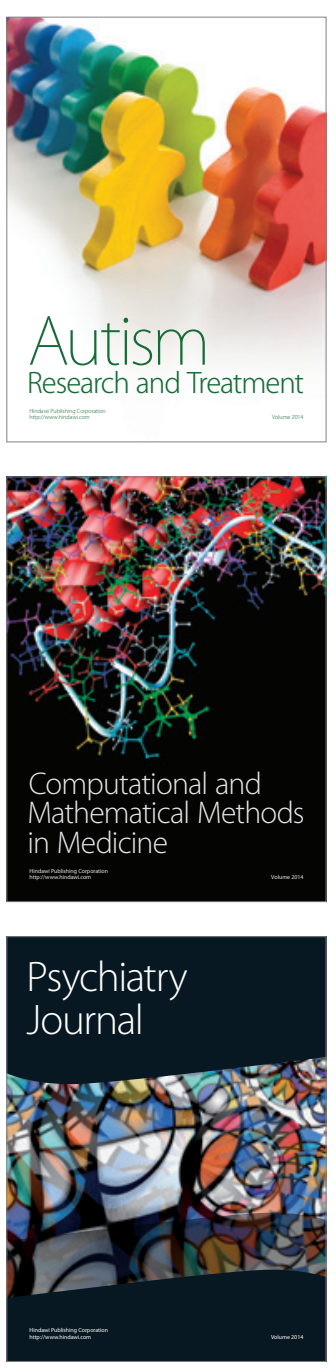
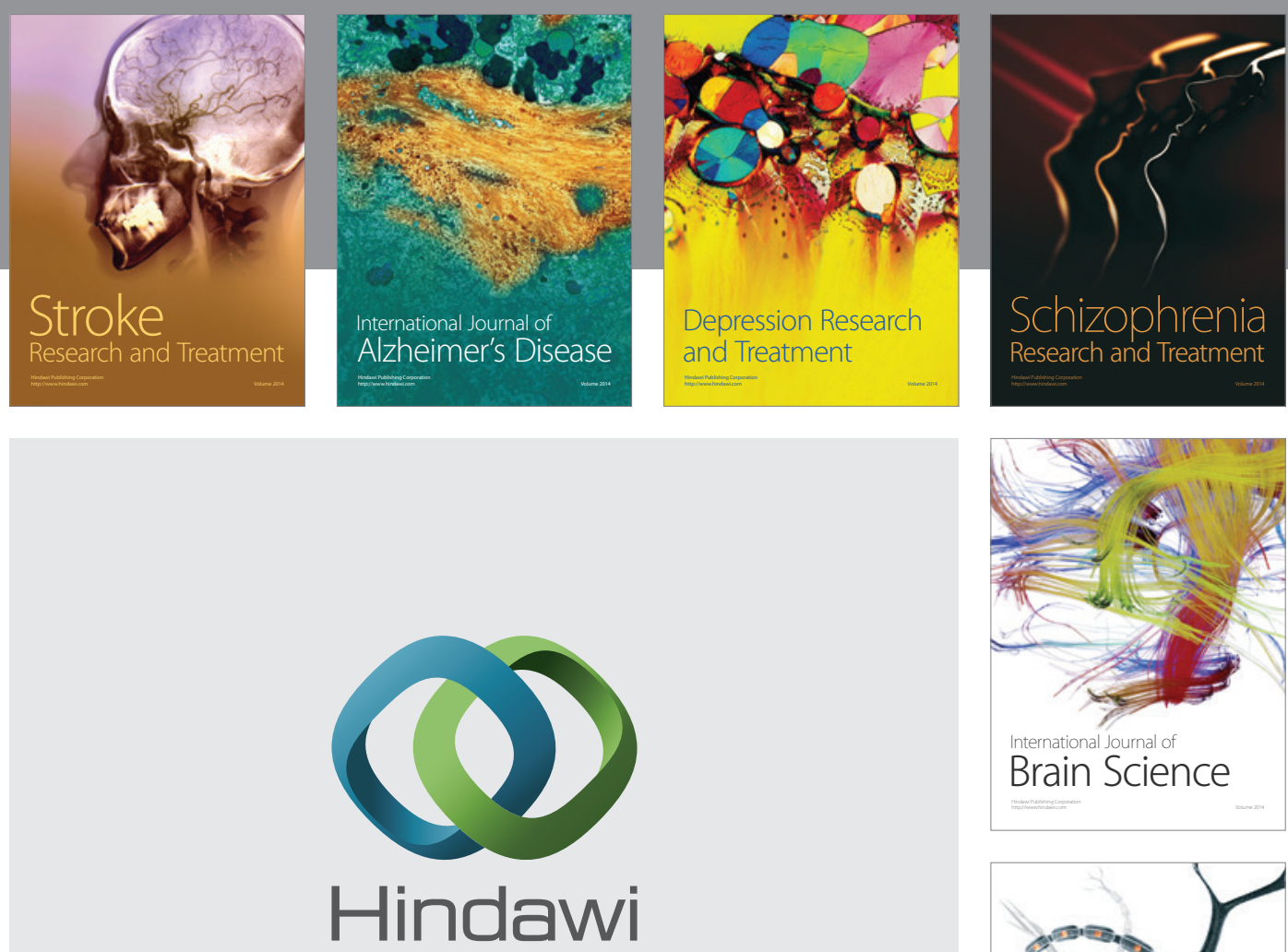

Submit your manuscripts at

http://www.hindawi.com
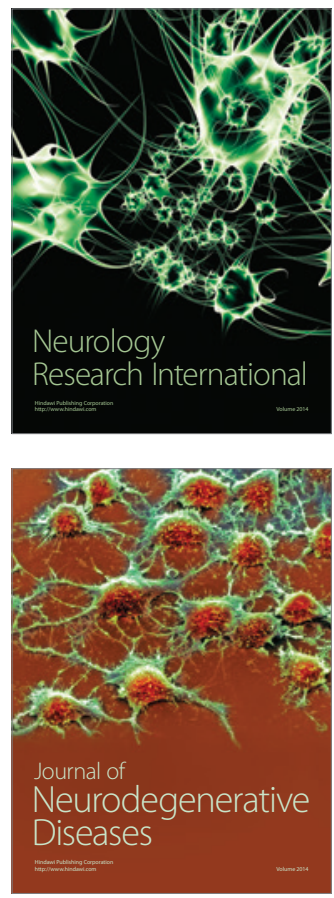

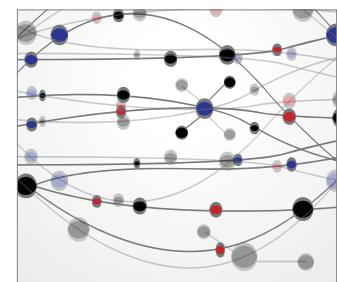

The Scientific World Journal
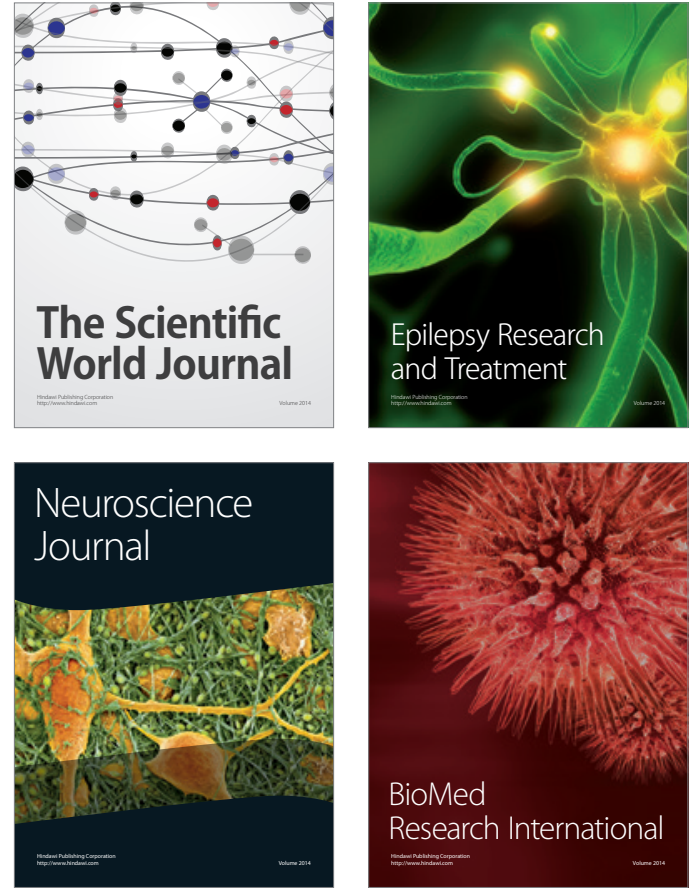

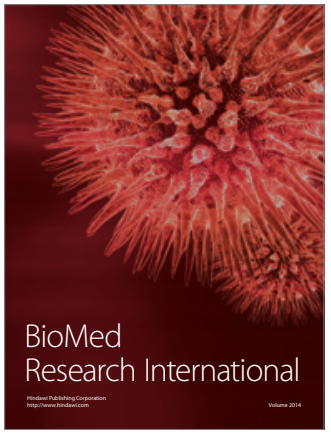

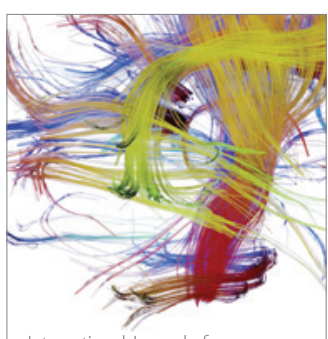

Brain Science

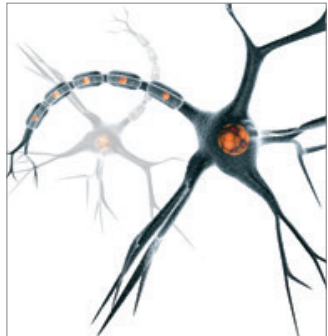

Neural Plasticity
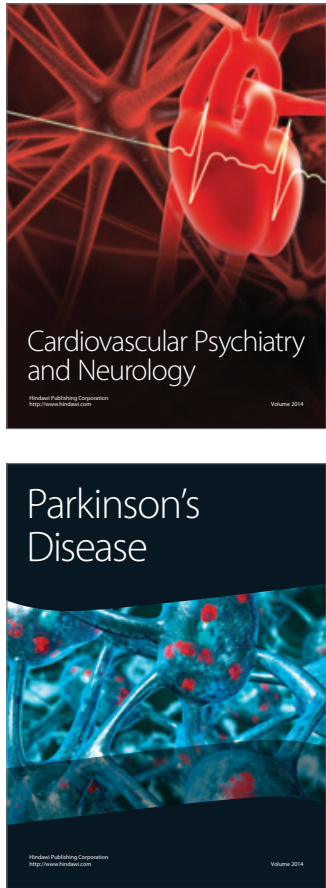